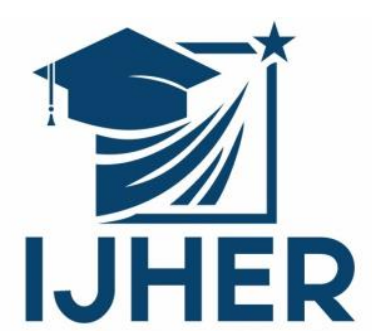

International Journal of Humanities and Educational Research

Volume 2, Issue 4, December 2020, p.38-60

İstanbul / Türkiye

\title{
THE GLORIOUS QUR'AN AND THE ARABIC LANGUAGE SOVEREIGNTY
}

http://dx.doi.org/10.47832/2757-5403.4-2.3

HAIDER AL-ZUBAIDY 1

ISSN: $2757-5403$

\section{Article Information}

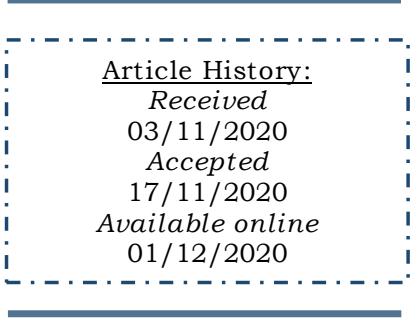

This article has been scanned by iThenticat No plagiarism detected

Copyright (C) Published by Rimak Journal, www.rimakjournal.com

Rimar Academy, Fatih, Istanbul, 34093 Turkey All rights reserved

\section{Abstract}

The current paper highlights the strong relation between the Arabic Language and its divine book- the Glorious Qur'anBesides, this relation and its diversified types are crystal clear in the Glorious book. Moreover, they have great influences on Arabs and the Arabic language as well. The first speaks about the horizon of extension in our glorious Arabic Language and its greatest.

The second examplifying some analytic examples for the pheneweron of significance-extensity in the Holy Quran.

The third showes a chosen groups of affecting Pheneweuons on significance-extensity extending the sewantic horizons and fumally the couclusion which contains the main results I have reached with an index of sources and referuces of the research. These impacts are as follows: Arab people moved from desert areas of the peninsula to cities and the ascended the throne of domination and sovereignty and maintaining the integrity of the Arabic Language by unifying this great language and expanding aspects of languages and its uses not to mention other impacts that will be found by the readers in the body of the paper.

Keywords: Quran, Arabic, Care, Sovereignty, Preservation, Evolution, Refinement, Expansion, Transcendence.

\footnotetext{
${ }^{1}$ Prof. Dr. Haider Ali Ni'mah AL-ZUBAIDY, College of Arts, Iraqia University, Iraq. dr.haider2020arts@gmail.com

\section{IJHER}

International Journal of Humanities and Educational Research

Volume 2, Issue 4, December 2020, p.38-60
} 


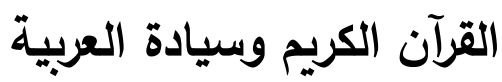

\author{
حيار نعمة 2
}

\begin{abstract}
ملخص
تطرق البحث لبيان مدى العلاقة الوطيدة المُبرمة بين اللغة العربية وكتابها الأكبر - القرآن الكريم - بحكم

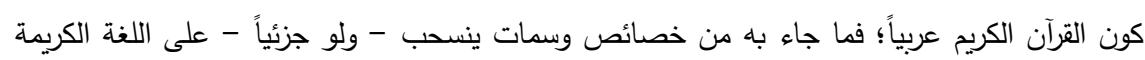

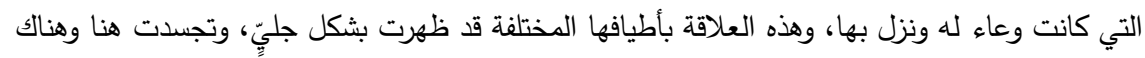

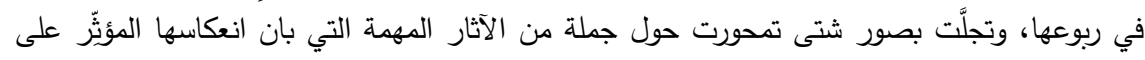

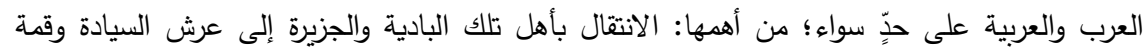

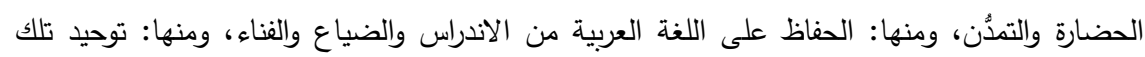

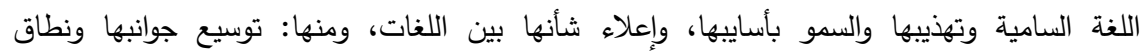

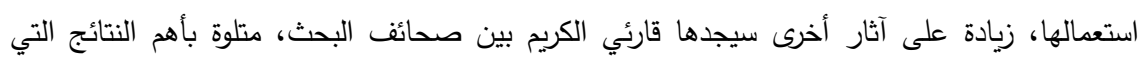
اكتنفها البحث، وثبت لأهم المصادر والمراجع التي أفدت منها في إثراء المادة العلمية للبحث.

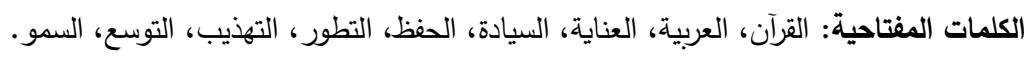

المقدمة

لم يحظَ كتابُ في الوجود بما حظي به القرآن الكريم من بحث وتتقيب ودراسة، ومن تواردٍ للعلماء وتضافرٍ

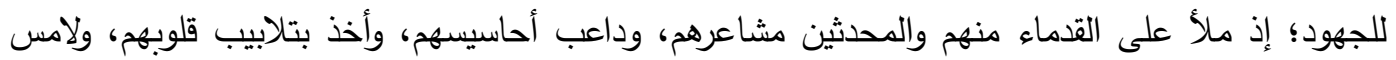

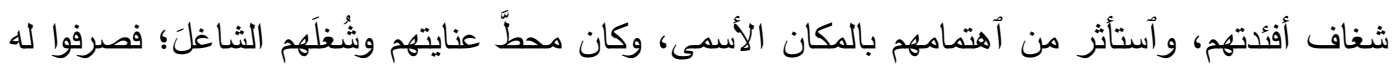

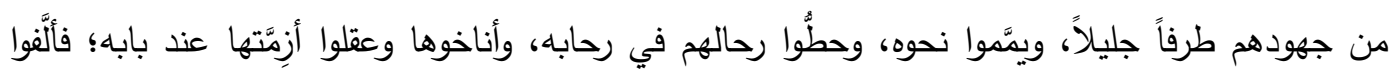

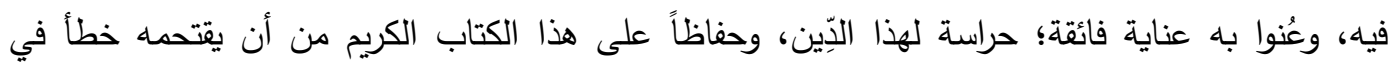

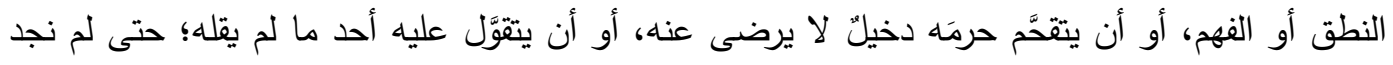

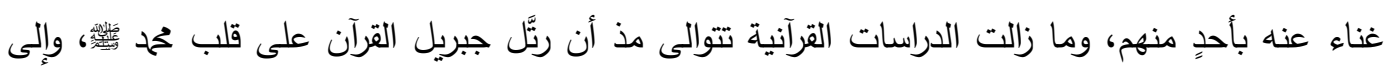
يوم الناس هذا. إن أنصراف العبد إلى كتاب ربه؛ لمحاوله فهمه وتفهيمه، والكشف عما يفتح الله له من مغاليقه لنعمة مسبغة جزيلة ترفع صاحبها عن سفاسف دنياه، وتبارك له في لحظات عمره؛ فيصحو من غفلة وسبات، وينتضر من يُبس وفتات، ويرقَّ من غلظة مجفاة، ويتلألاً بالنور يكسوه الجمال والبهاء؛ فهو مع كل حرف يروزه

\footnotetext{
2 الأستاذ الدكتور : حيدر علي نعمة، كلية الآداب (قسم علوم القرآن)، الجامعة العراقية، العراق. dr.haider2020arts@gmail.com

\section{IJHER}

International Journal of Humanities and Educational Research

Volume 2, Issue 4, December 2020, p.38-60
} 
ويتملَّها ويستذوقه؛ علَّه يكشف الخبيء من سره، ويطاوع العصيَّ من معناه؛ يشعر بفيض النعمة الإلهية تستحق كل ثناء عليه!

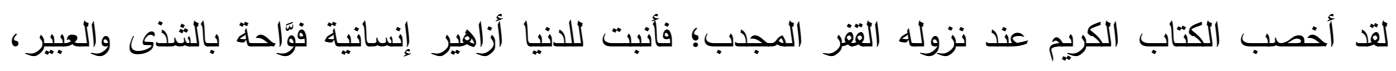

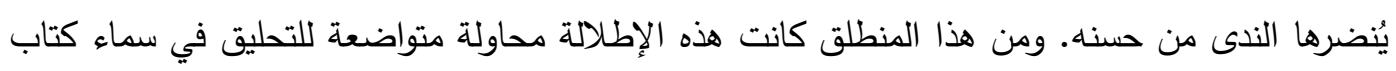
الله، وفي فضاء نصه المترامي، والوقوف على تخومه وأطرافه؛ بغيه أستخراج بعض من درن دره ولآلآلئه الأخَّاذة

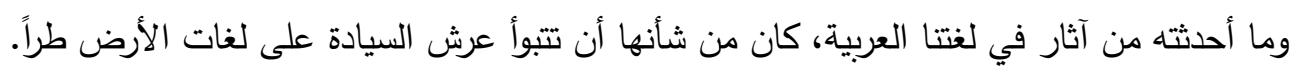

\section{آثار القرآن الكريم في العرب وإلعربية}

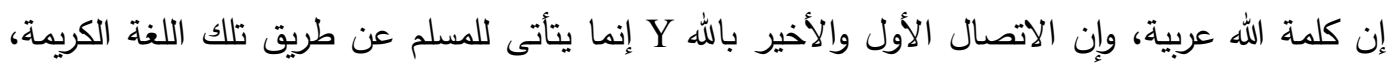
يعرف من خلالها ما عليه من أعمال وواجبات، وما له من حقوق وآمتيازات؛ فاللغة - إذاً - هي مركز لإنه الاتصال والتلاقي بين الخالق والمخلوق، وهي المفتاح لفهم حقيقة هذا الوجود، ومعرفة المزيد عما ينتظره

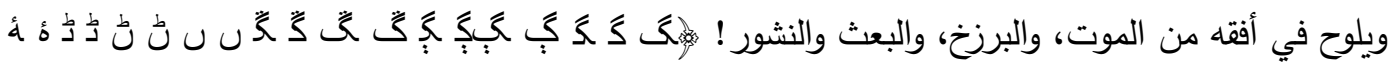

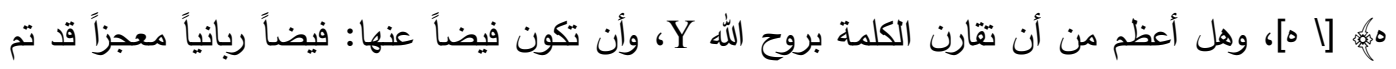

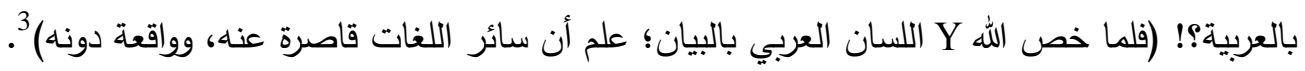

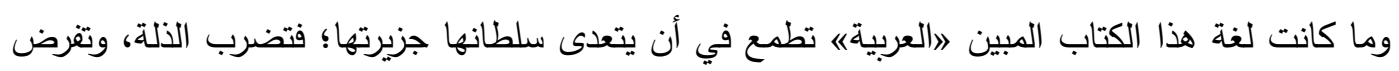

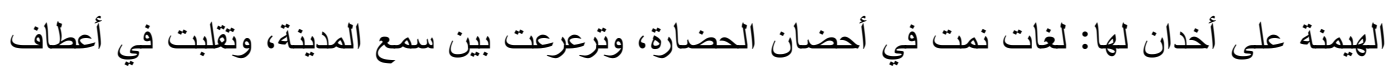

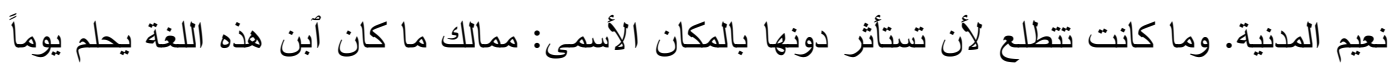

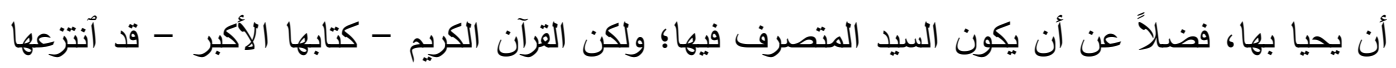

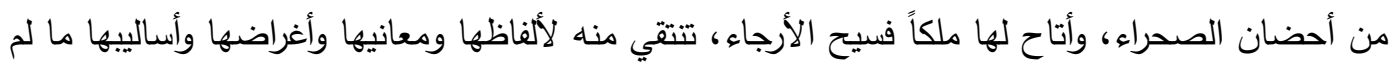

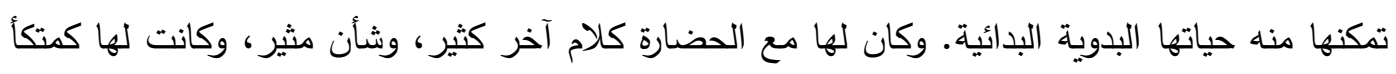
مخملي وثير • فبعد أن كانت ثروتها في حدود بيئتها؛ غدت غنية فئية في كل فنون الحياة؛ فأقبل الناس إليها،

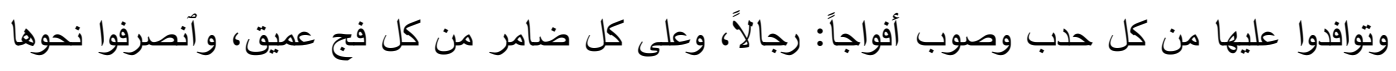

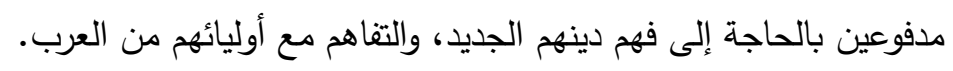

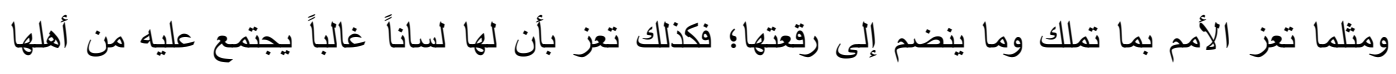

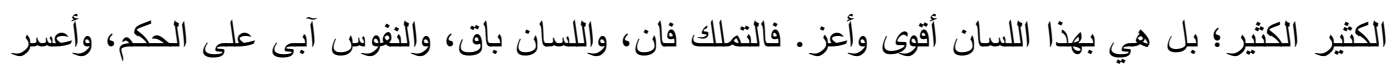

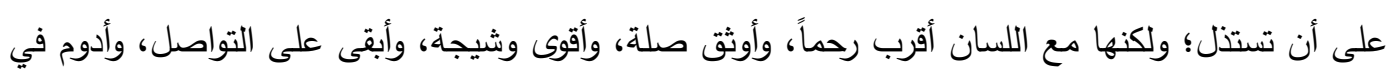
العطاء 4

3 الصاحبي/28 ص4، وينظر: اللسان العببي مظهر لغوي للمعزة الإلهية الخالدة (القرآن الكريح)، مجلة الضاد (العدد الرابع -1410هـ/

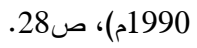

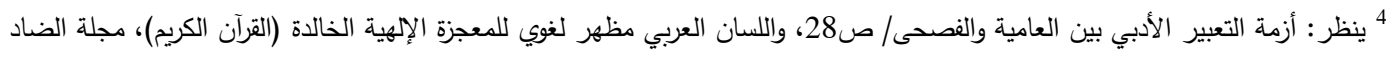

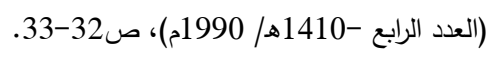

\section{IJHER}

International Journal of Humanities and Educational Research

Volume 2, Issue 4, December 2020, p.38-60 
هكذا كانت العربية مع الإسلام: لغة قامت معها للعرب دولة الكلام؛ لكن هذه الدولة بقيت بلا ملك حتى

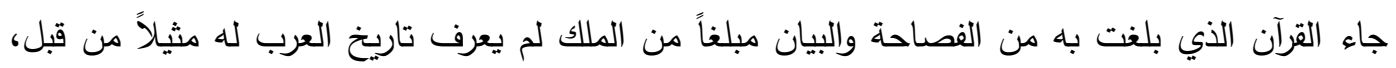

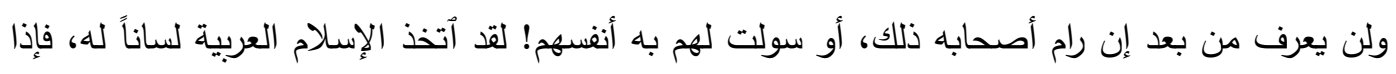
كان الإيمان به هداية ونوراً؛ كان الإسلام من ذلك النور طبيعته وحقيقته، وكانت اللغة العربية منه المظهر لإنه

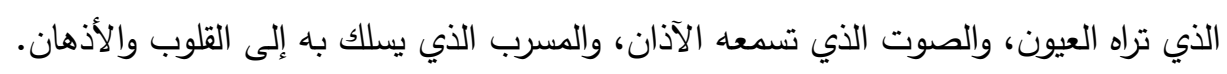

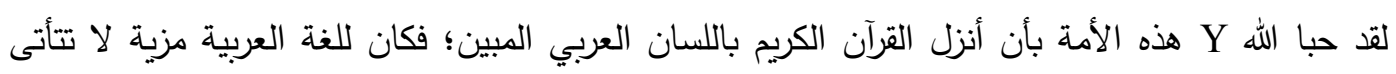

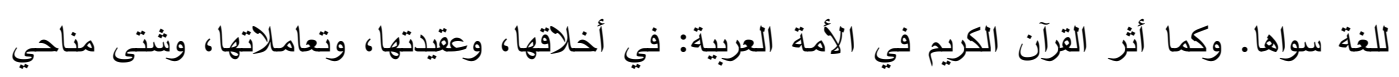

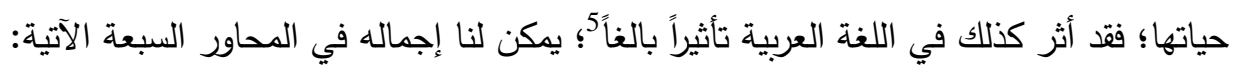

\section{الحفاظ على اللغة العربية من الاندراس والضياع والفناء}

لقد تسنت للعربية الفصحى ظروف خاصة لم تتوافر لأي من لغات العالم جمع؛ ذلك لأنها أرتبطت بالترآن

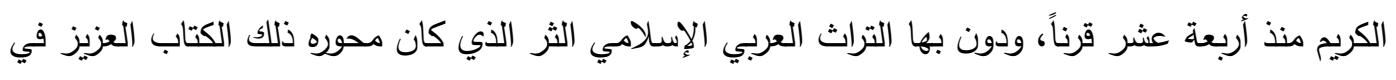

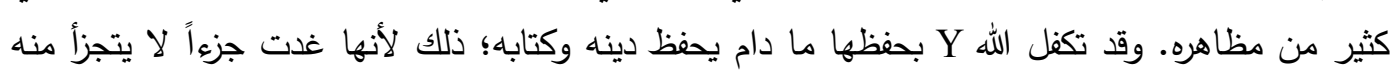

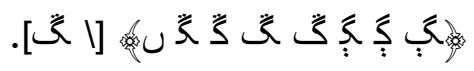

(وقد توافر علماؤنا ه على العناية باللغة العربية منذ ظهور الإسلام، وأصبح العلم باللغة العربية وعلومها

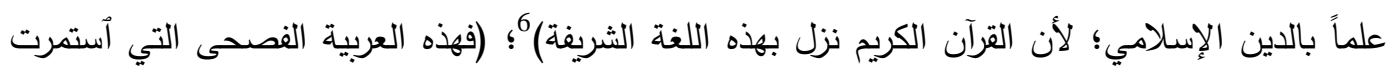

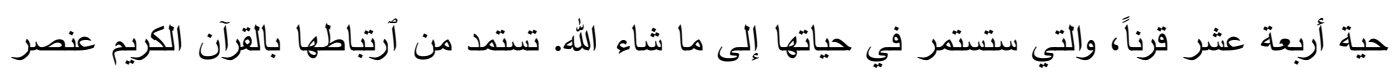
الحياة 7.

ولولا أن شرف الله Y تلك اللغة؛ فأنزل بها كتابه، وقيض له من خلقه من يتلوه صباح مساء، ووعد بحفظه

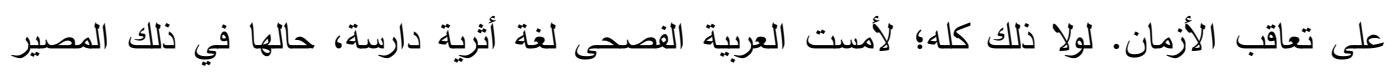

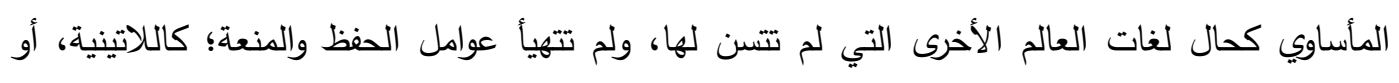

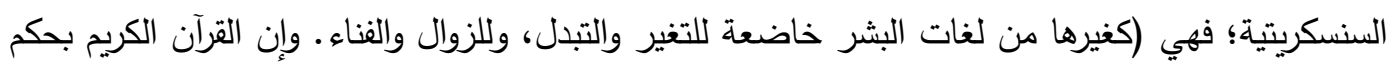

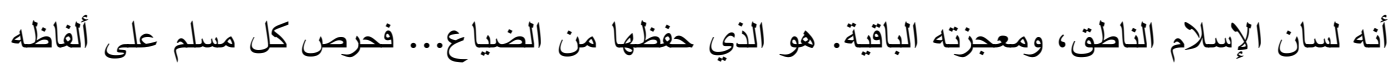

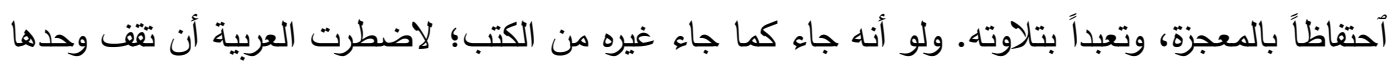

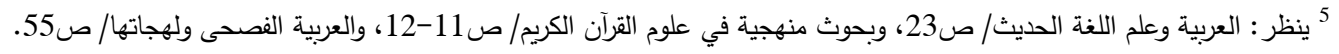

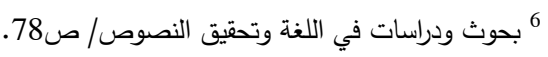

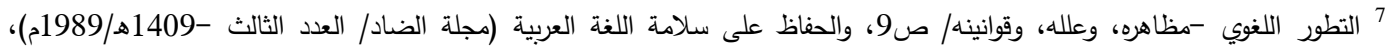

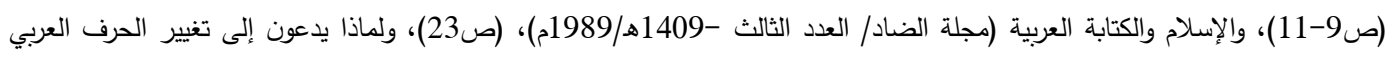

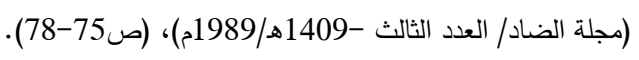

\section{IJHER}

International Journal of Humanities and Educational Research

Volume 2, Issue 4, December 2020, p.38-60 
في معترك الحياة؛ فلا تزال تتطلع إلى التجديد حتى تصبح في مبدئها ونهايتها لغتين أو لغات متباينة، أو إو الوتى

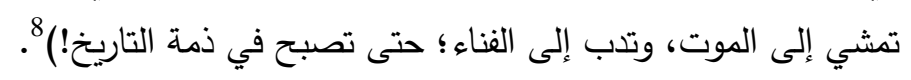

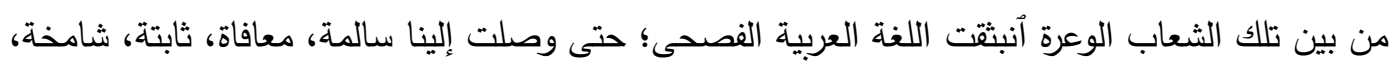

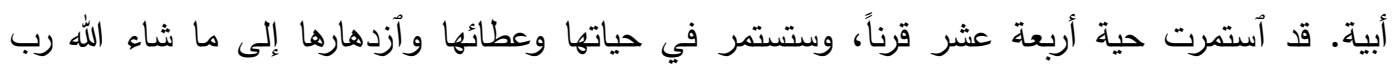

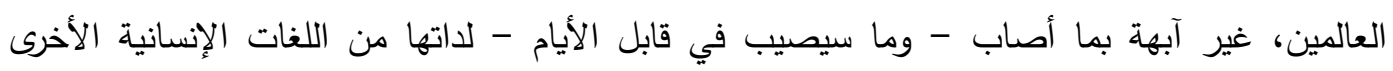

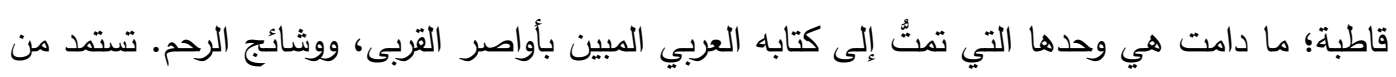

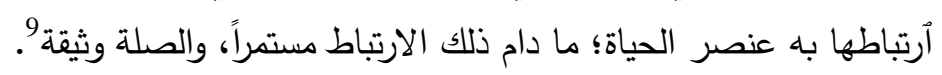

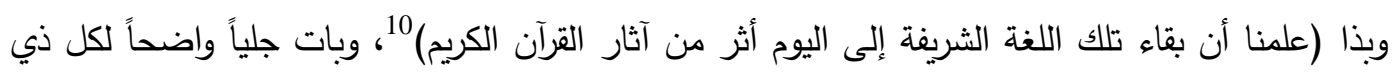

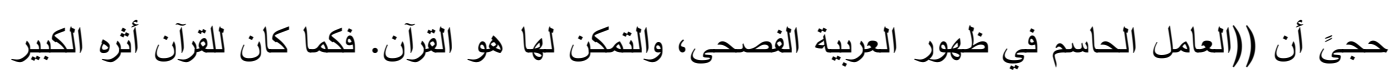

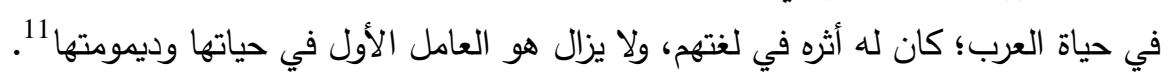

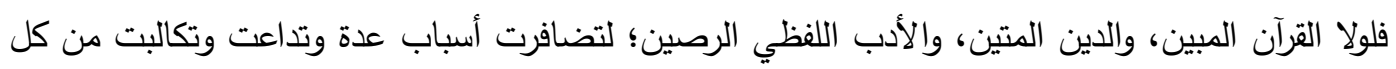

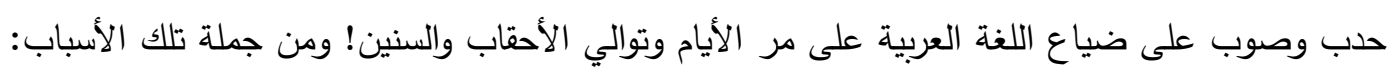

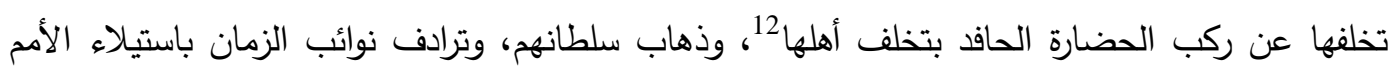

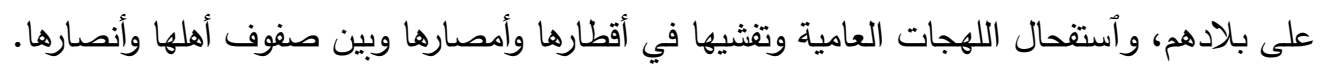

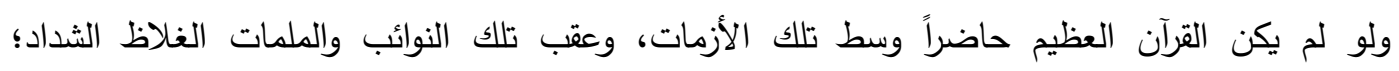

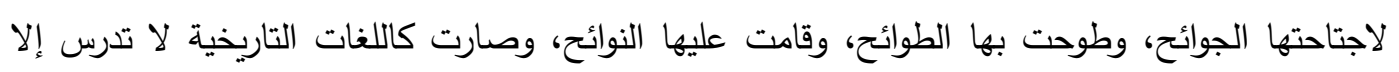

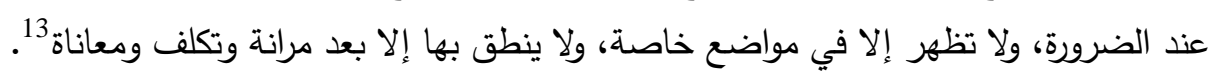

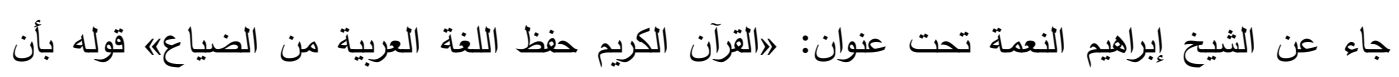

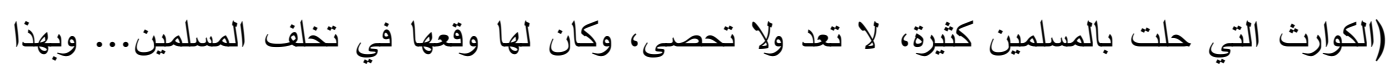

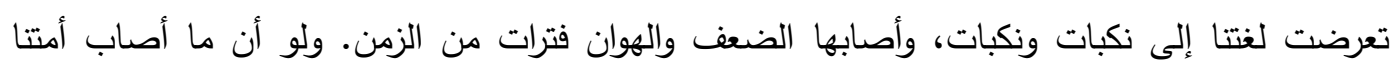

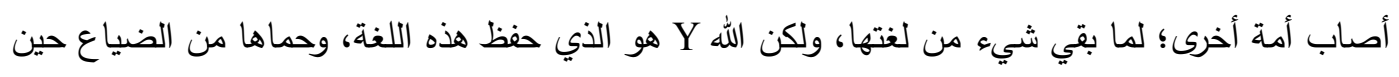

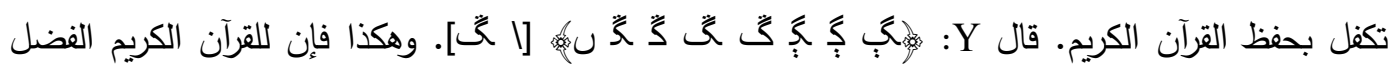

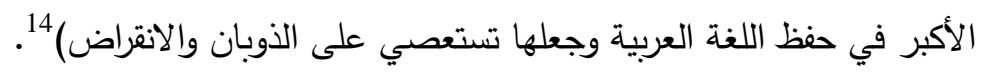

8 أثر القرآن الكريم في اللغة العربية/صب34- ص-35.

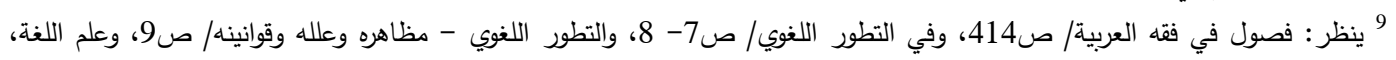

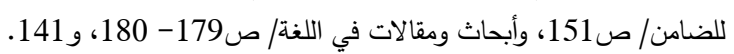
10

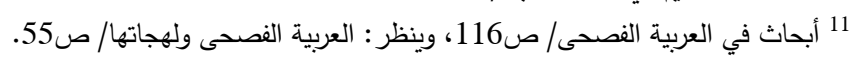

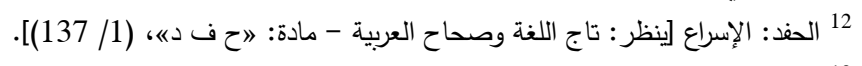

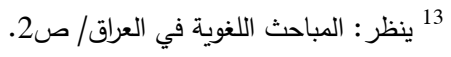

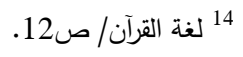

\section{IJHER}

International Journal of Humanities and Educational Research

Volume 2, Issue 4, December 2020, p.38-60 


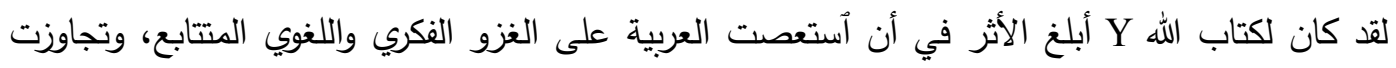

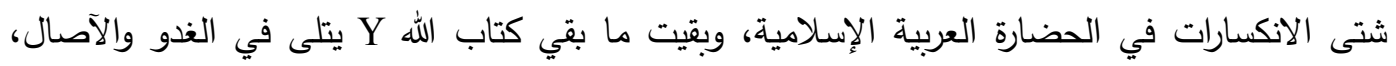

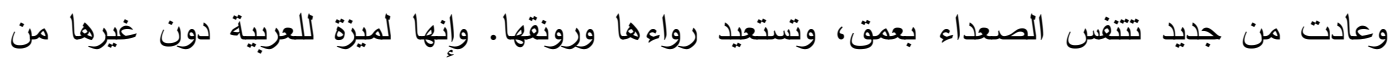

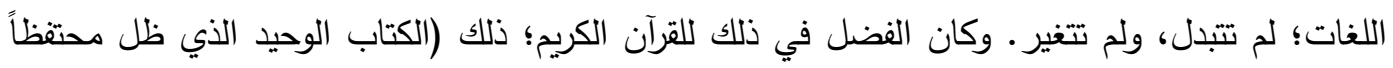

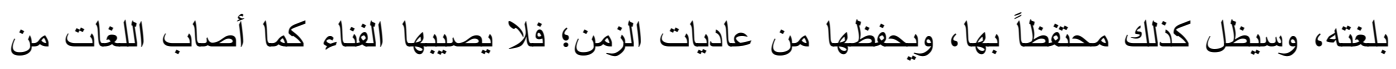
قبلها؛ بل ستظل باقية ما بقي الليل والنهار ؛ لأنها لغة القرآن) قال المستشرق المجري "عبد الكريم جرمانوس《: (إن في الإسلام سنداً هاماً للغة العربية، أبقى على روعتها

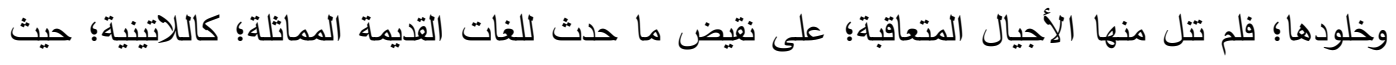
أنزوت تماماً بين جدران المعابد! ولقد كان للإسلام قوة تحويل جارفة أثرت في الثعوب التي أعتنقته حديثاً، وكان لأسلوب القرآن الكريم أثر عميق في خيال هذه الثعوب؛ فاقتتبست آلافاً من الكلمات العربية أزدانت بها لغاتها الأصلية؛ فازدادت قوة ونماءً) وقال المستشرق الألماني 》تيودور نولدكه Theodor Noldeke《 عن العربية وفضلها الذي لا يتوارى وقيمتها

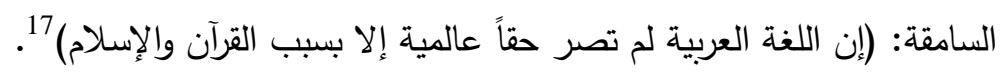

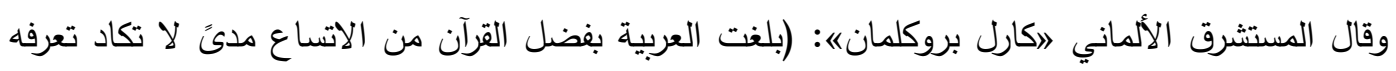

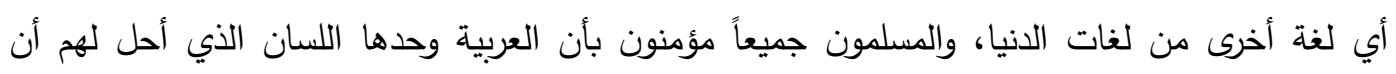

$$
\text { يستعملوه في صلاتهم) }
$$

وهكذا نرى بوضوح تام (أن القرآن الكريم كان محوراً لجمع الدراسات العربية التي قامت في الأساس لخدمته.

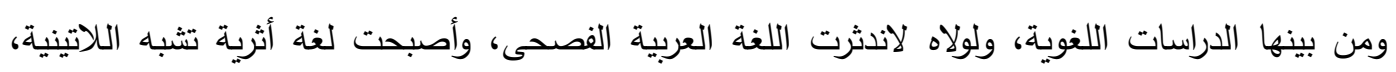

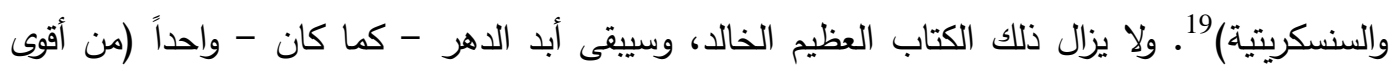
أسباب بقاء العربية، ومن أهم عوامل أنتشارها بين أبناء الثعوب الإسلامية غير العربية في العالم كلها...

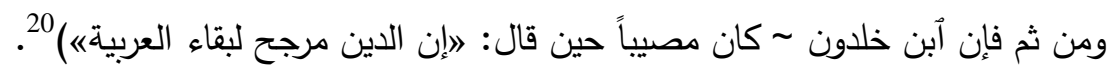

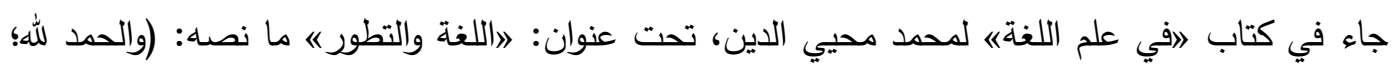
فقد حافظ القرآن الكريم على لغتا من الاندثار ؛ لأن التطور - أي التغير باستمرار - يجعل اللغة تنقد

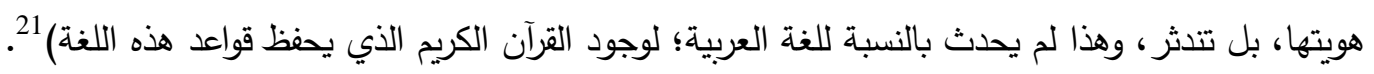

15 لغة القرآن/ ص14، وينظر : أبحاث ومقالات في اللغة/ ص171، ولغة الضاد/ بحث: لماذا يحارب الحرف العربي؟! ص 56.

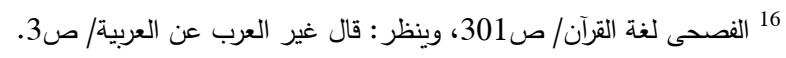

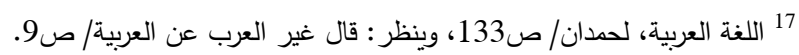

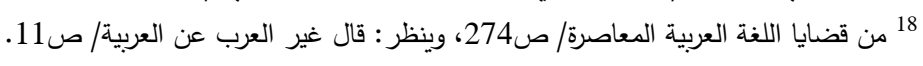

19 فصول في فقه العربية/ صن فيايا للغة العربة العاصرة

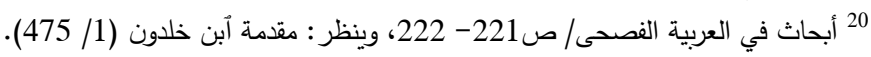

أبحاث 121

\section{IJHER}

International Journal of Humanities and Educational Research

Volume 2, Issue 4, December 2020, p.38-60 
بتضافر تلك العوامل غدت (لغة القرآن الكريم من اللغات الحية التي لا تموت، ولا تتقرض، ولا ينتابها القصور ؛ وذلك لأنها مرتبطة بكتاب سماوي مقدس... وسر ذلك أنه ما دام مسلم على وجه هذه المعمورة

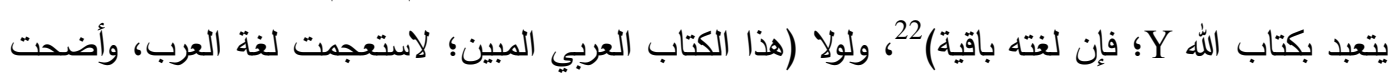

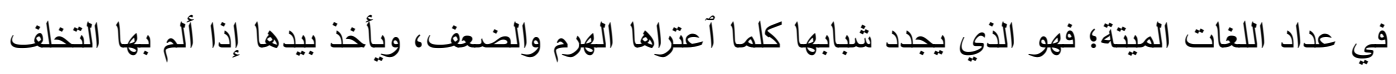
والركود)

\section{توحيد اللغة العربية}

لا مناص من القول بأن واحداً من مظاهر آرتباط اللغة العربية بمصدرها الأصيل 》القرآن الكريمه وتأثيره

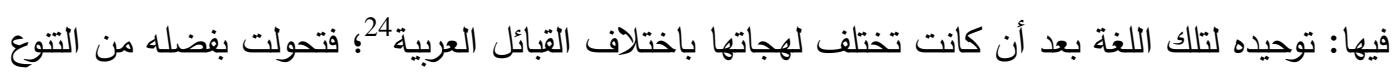

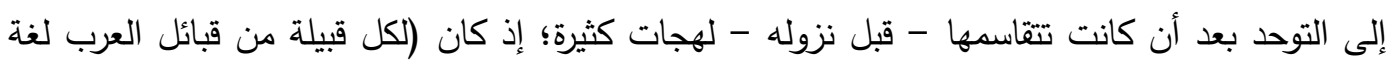

$$
\text { تنغرد بها، ويؤخذ عنها) }
$$

وكأي من حال؛ (فقد وضح للك أنه لولا القرآن وأسراره البيانية؛ ما آجتمع العرب على لغته. ولو لم يجتمعوا؛ لتبدلت لغاتهم بالاختلاط الذي وقع ولم يكن منه بد... وهكذا يتسلسل الأمر حتى تستبهم العربية؛ فلا تبين

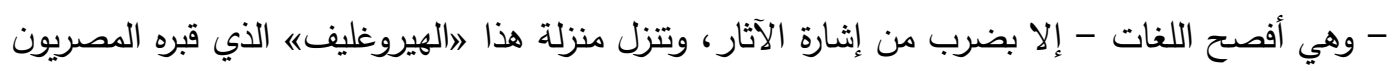

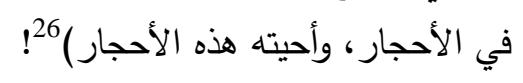

قال الرافعي في معرض حديثه عن الجنسية العربية في القرآن: (فبقاء القرآن على وجهه العربي مما يجعل

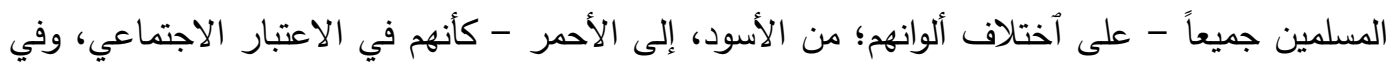
أُعتبار أنفسهم جسم واحد ينطق في لغة التاريخ بلسان واحد) من وأضاف: (ومن المعلوم بالضرورة أن القرآن

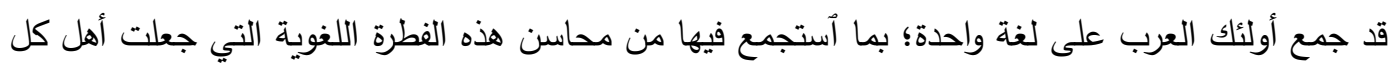

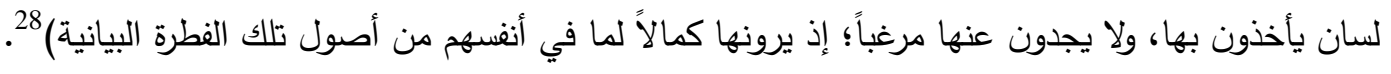
وبذا أقام 》القرآن الكريمه للعرب جامعة تم من خلالها توحيدهم تحت لوائه، يسيرون على منواله، ويتفيأون

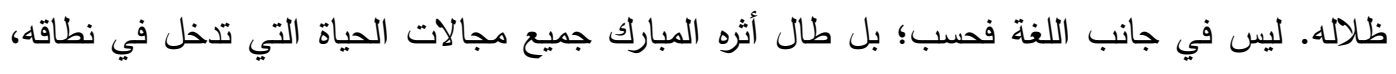
وكلها داخلة في نطاقه، (وبه صار العرب أمة واحدة، مؤمنة، موحدة، متآلفة القلوب، متجانسة المزاج،

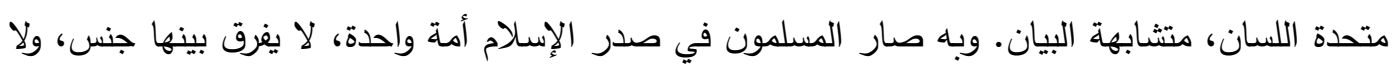

$$
\begin{aligned}
& 22 \text { مناهج وآراء في لغة القرآن/ ص5. }
\end{aligned}
$$

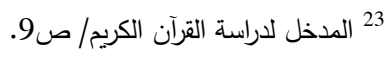

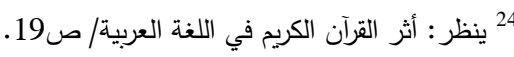

$$
\begin{aligned}
& 27 \text { الررجع نفسه (1/ 88) }
\end{aligned}
$$

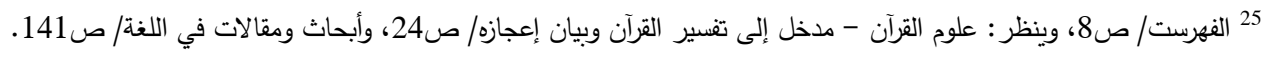

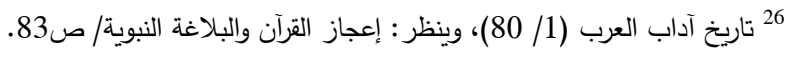

\section{IJHER}

International Journal of Humanities and Educational Research

Volume 2, Issue 4, December 2020, p.38-60 
لون، ولا لغة؛ فقد أنصهرت كل هذه الفوارق في نور الإسلام، ولم ييق إلا الاعتزاز بالإسلام والقرآن).29. وفي هذا السياق يقول الإمام أحمد بن فارس : (كانت العرب في جاهليتها على إرث من إرث إلى آبائهم في لغاتهم وآدابهم ونسائكهم وقرابينهم. فلما جاء الله Y بالإسلام؛ حالت أحوال، ونسخت ديانات، وأبطلت أمور ،

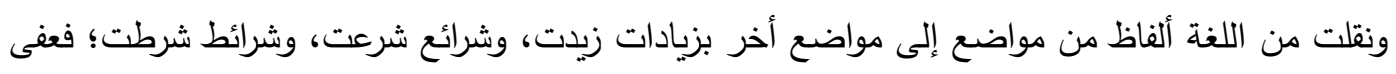

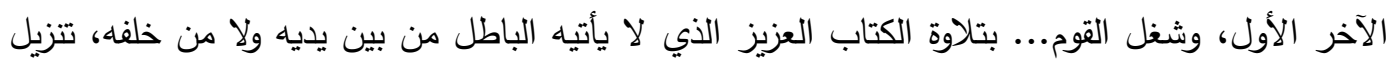

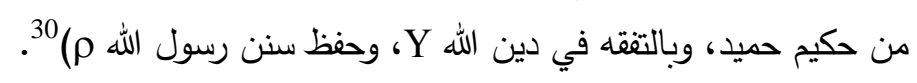

\section{تهذيب اللغة العربية}

وهذا هو المحور الثالث من عوامل تأثير القرآن الحكيم في لغته العربية المجيدة؛ فزيادة على ما تقدم؛ فقد (صفى القرآن الكريم هذه اللغة؛ فأشاع في الاستعمال أصفى ألفاظها جرساً، وأدقها تعبيراً، وأحلاها نغماً، وأورد كل لفظة في مكانها المناسب ببراعة فائقة، وآلتزم الدقة في مراعاة دلالة الألفاظ، وإيرادها مواردها

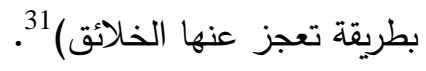

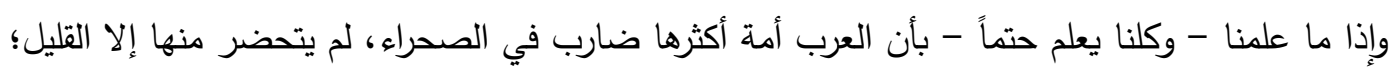
فلا جرم أن كان في لغتهم الخشن الجاف، والحوشي الغريب! ولعل من يقرأ الأدب الجاهلي ويتدبره؛ يزداد

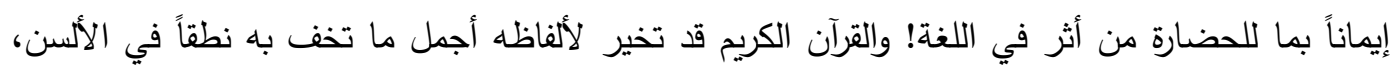

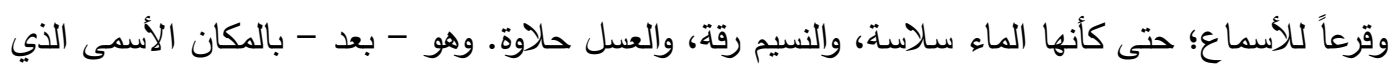

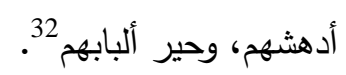

وعقب أن رازوا333 قواهم في أفانين البلاغة المختلفة؛ وهم من هم. جهابذة اللغة، وأساطين الفصاحة، وفرسان

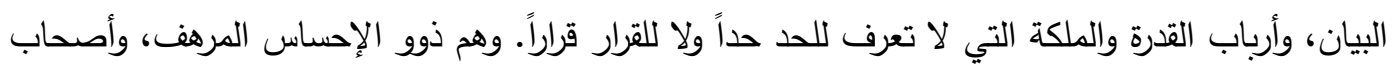

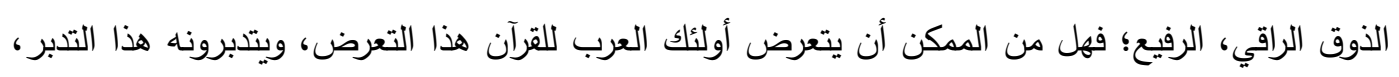

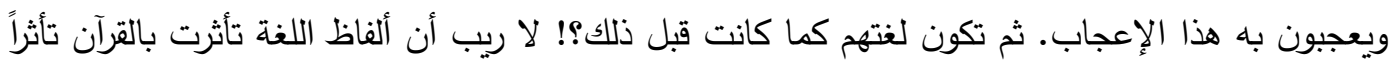
بالغاً. (وكما أثر القرآن في معاني اللغة من حيث ما جاء به من أشتراع جديد؛ كان له أثر في خلق معان جديدة

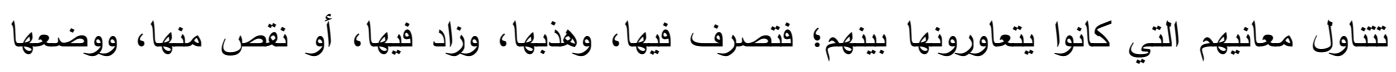

29 المذخل لدراسة القرآن الكريم/ ص9.

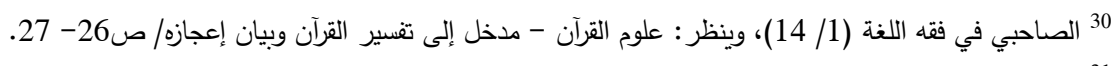

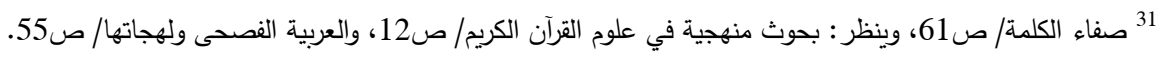

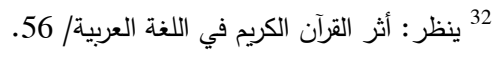

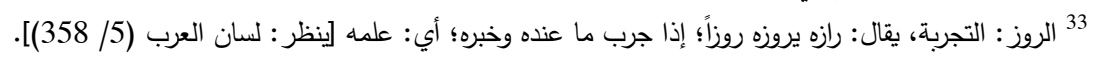

\section{IJHER}

International Journal of Humanities and Educational Research

Volume 2, Issue 4, December 2020, p.38-60 
مواضع تتاسبها؛ بحيث أصبحت تلائم كل الأذواق في كل العصور • بعد أن كان فيها ما لا يسمح لها

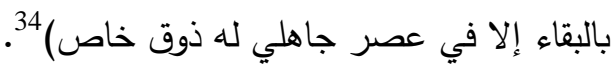
لقد كان لكتاب الله Y في تهذيب تلك اللغة الباع الطولى؛ إذ نحى عنها التقعر في الكلام، والغريب، والألفاظ الحوشية الثقيلة على السمع. ومن يتأمل منثور العرب قبل نزول القرآن، ويتصفح في الثعر الثرك الجاهلي؛ ييصر كثيراً من الكلمات الحوشية، والتراكيب المستهنة، والألفاظ الثقيلة، والأصوات النابية؛ مثل:

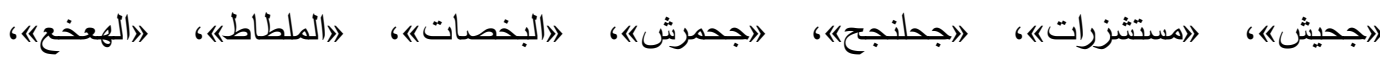
|أفرنقعواه... وغير ذلك كثير 35.

\section{السمو باللغةة العربية}

لقد (لقيت العربية في العصور المتقدمة شموخاً ورفعة بين لغات الأرض بعد نزول القرآن الكريم، وبدء

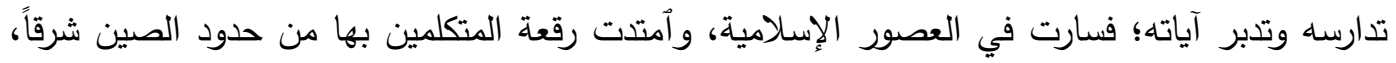

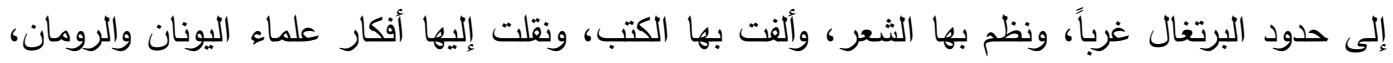
ونقلت هي أفكار علماء المسلمين من الفقهاء والفلاسفة والمفكرين، وأستوعبت الحضارات البشرية الوافدة ولفي على المجتمع الإسلامي؛ فتعربت مفردات العلوم، وترجمت النصوص العلمية والأدبية والثقافية)

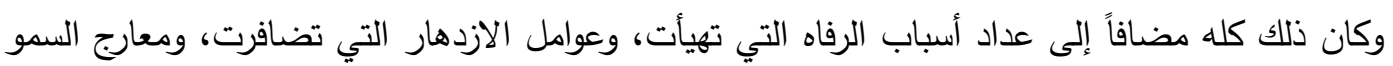

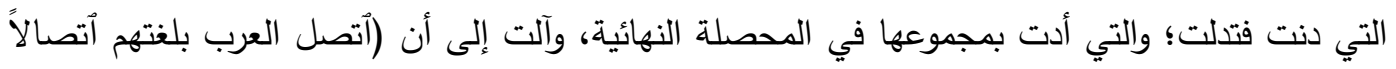
وثيقاً، لا نرى له مثيلاً في الأمم الأخرى، وأسعفتهم بما يعوزهم، ووفوا لها فكانوا أمناء محافظين عليها) وبذا نجد اللغة العربية المجيدة قد (خطت خطوات واسعة بنزول القرآن الكريم؛ فازدهرت ألفاظاً ودلالات وأساليب وصوراً، وبدأت الألفاظ القرآنية بدلالاتها الجديدة تدخل معجم الشعراء والخطباء، والمتحدثين،

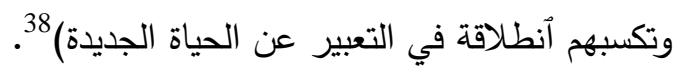

فاللغة العربية الفصحى لم تخلد على مر الأزمان، ولم يمتد بها العمر أربعة عشر قرناً، وإلى ما شاء الله

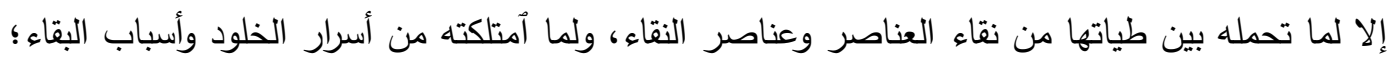

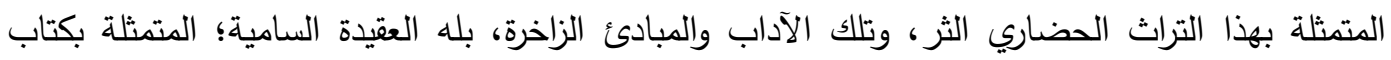

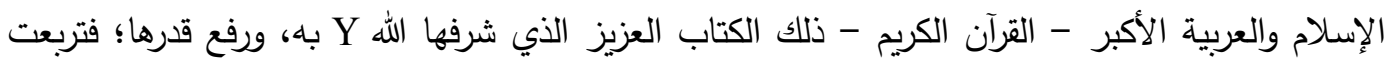
على عرش السيادة، وتوجت بتاج السيادة والملك على سائر أخدانها من لغات العالم الأخرى جمع لـعزئ.

$$
\begin{aligned}
& 34 \text { أثر القرآن الكريم في اللغة العربية/ص96، صوينظر : أبحاث ومقالات في اللغة/ص141. }
\end{aligned}
$$

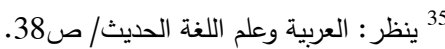

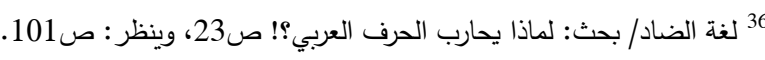

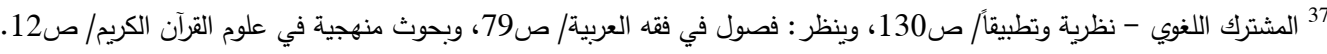

\section{IJHER}

International Journal of Humanities and Educational Research

Volume 2, Issue 4, December 2020, p.38-60 
كما كان للقرآن أثره البالغ، ودوره الفاعل في الرقي بدلالات كثير من الألفاظب؛ كلفظ »الرسوله الذي كان

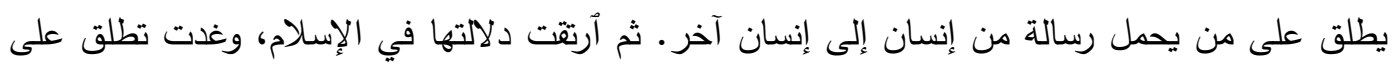

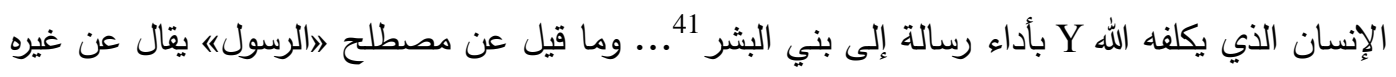

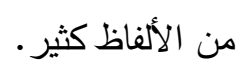

إن المتصفح لتاريخ الأمة العربية، وطبائعها، ومميزاتها؛ يرى من سلامة عنصرها، وصفاء جوهرها، وسمو

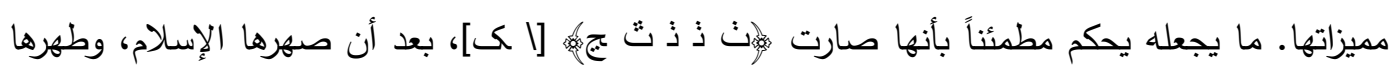

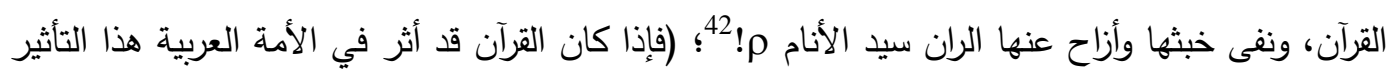

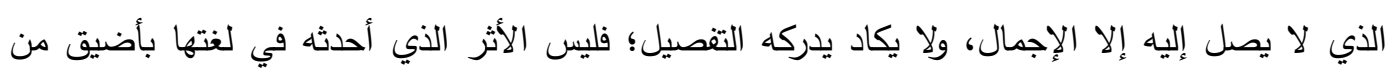

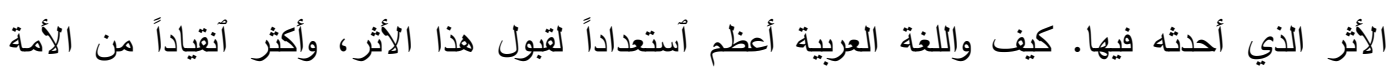
العربية؟!) الأن

وما من ريب في (أن القرآن الكريم هو الذي أخرج العرب فعلاً، وشق لهم طريق المجد، ومهح للغتهم سبيل

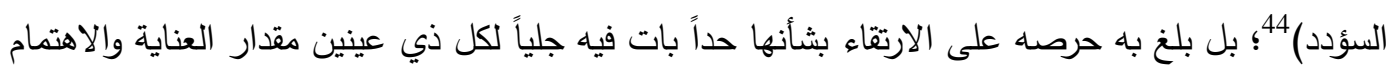
من ذلك الكتاب المبارك بتلك اللغة المجتباة؛ ف (لما بزغت شمس الإسلام من سماء القرآن؛ أكتسبت اللغة العربية قوة في البيان، وجزالة في اللفظ، وفخامة في المعنى؛ بما تشتمل عليه من ألفاظ موحية، وكلمات

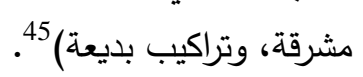

ومن أهم المظاهر العديدة الأخرى لذلك الارتباط المتين، والعرى الوثيقة التي وصلت اللغة العربية بالقرآن

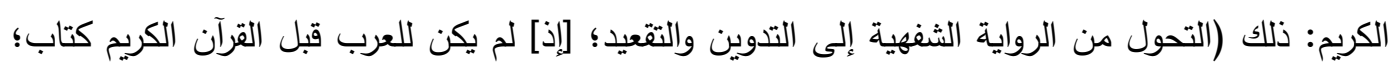

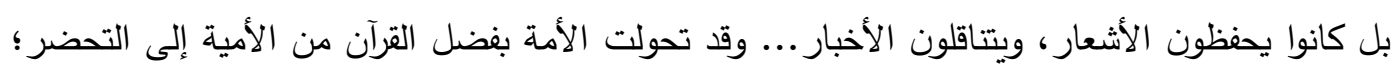

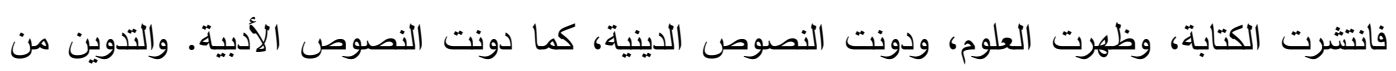
لوازم حيوية اللغة وديمومتها...).46. ومن أهم تلك المظاهر الأخرى: أرتباط العربية بالقرآن الكريم، ونشأة علوم العربية؛ إذ (لا يخفى على القارئ

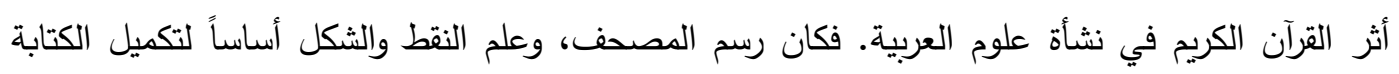

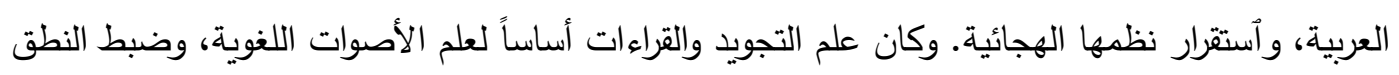

$$
\begin{aligned}
& 40 \text { ينظر : دلالة الألفاظ/ ص90. }
\end{aligned}
$$

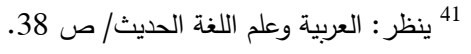

$$
\begin{aligned}
& 42 \text { هناهل العرفان في علوم القرآن (1/ 330) }
\end{aligned}
$$

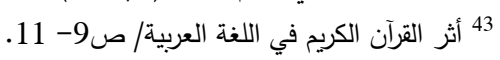

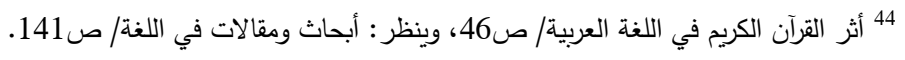

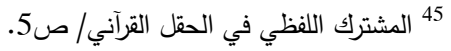

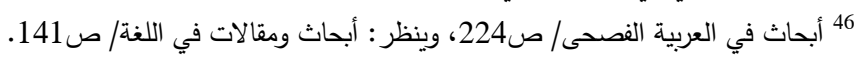

\section{IJHER}

International Journal of Humanities and Educational Research

Volume 2, Issue 4, December 2020, p.38-60 
العربي. وكان علم النحو والصرف يستجيب لحاجة الدارسين للبناء اللغوي للقرآن الكريم، كما كان علم

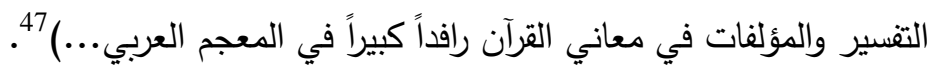

وإذا كان العرب الأوائل قد أوجدوا اللغة مفردات فانية؛ فإن القرآن المجيد قد أوجدها تراكيب خالدة باتية الثية، ونشأت لهذه اللغة فيما بعد معاجم كثيرة تجمع مفرداتها وأبنيتها؛ ولكن ليس لها معجم تركيبي غير القرآن

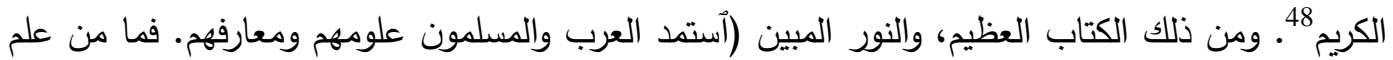
من علومهح إلا وله بالقرآن سبب، وله منه ورد ومدد)، وله ولولا تلك الوشائج الحميمة، والروابط المتينة. أو بعبارة أدق وأوثق: (لولا هذا الكتاب؛ لما كانت هذه الثروة الطائلة من العلوم التي تدور حول القرآن ولغة ولة التهات

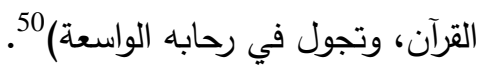

وبفضل هذا الكتاب العظيم، والنور المبين؛ فقد (حظيت العربية باهتمام علمائها أهتماماً لم تحظ به لغة غيرها منذ زمن مبكر فيما نجده من ضبط إعرابها، وبناء مفرداتها، وإحصاء ألفاظها، ودراسة ظواهرها، وتحليل بناها وتراكيبها ودلالاتها، ودراسة أصواتها. وتحول العمل اللغوي من محاولة ضبط فيط أدائها. وصولاًا

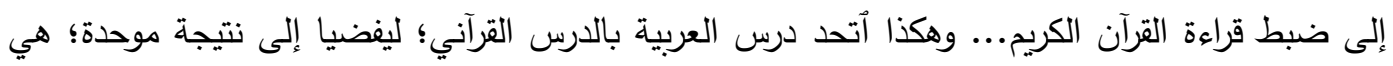

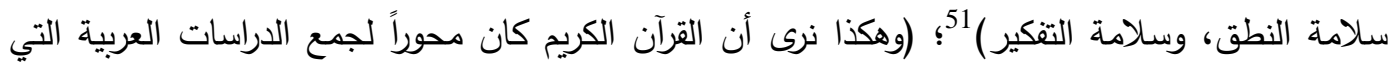

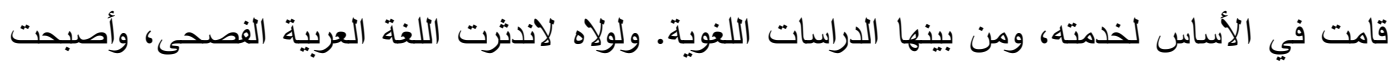
لغة أثرية تشبه اللاتينية، والسنسكريتية)

\section{توسيع جوانب اللغة العربية}

بعد أن تعرفنا - في جولة سريعة - على بعض الجوانب المهمة التي لا يجدر باهتمام الباحثين والدارسين

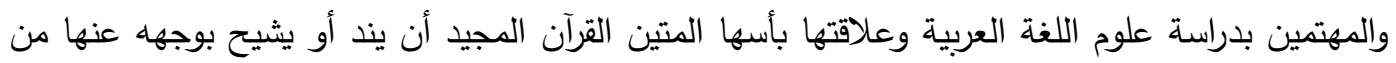

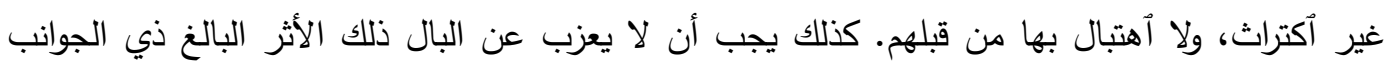

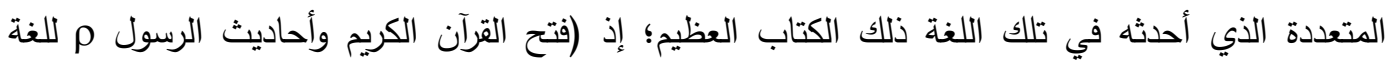
العربية أبواباً كثيرة من فنون القول؛ فعولجت بها أمور لم تكن العربية لتعنى بعلاجها من قبل؛ وذلك كمسائل

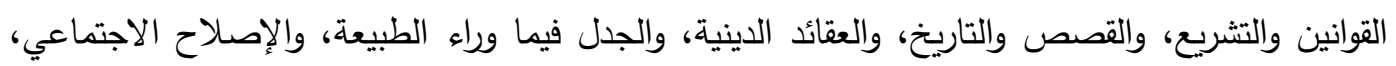

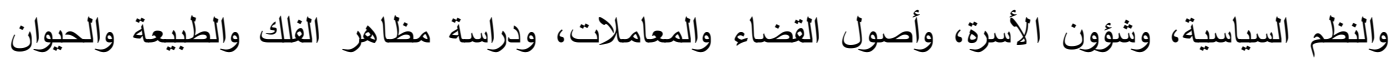

$$
\begin{aligned}
& 47 \text { المرجع نفسه/ ص226- تصن } 227 . \\
& 48 \text { ينظر : تاريخ آداب العرب (1/ 228)، وأثر الدلالات اللغوية في التفسير عند الطاهر بن عاشور/ ص775. }
\end{aligned}
$$

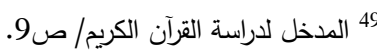

$$
\begin{aligned}
& 50 \\
& 51 \text { لغة الضاد (لماذا يحارب الحرف العربي؟!)، ص57، صئ وينظر : مقدمة الصحاح/ ص27. } \\
& \text { 5صول في فقه اللغة/ ص115. }
\end{aligned}
$$

\section{IJHER}

International Journal of Humanities and Educational Research

Volume 2, Issue 4, December 2020, p.38-60 
والنبات... وهلم جراً) 53، وقد عقد السيوطي في "إتقانه《 نوعاً خاصاً بالعلوم المستنبطة من ذلك الكتاب الكريم؛ وهو النوع الخامس والستون 54. وفي هذا السياق يقول الدكتور عدنان تحمد زرزور: (إن القرآن الكريم كان المحور الذي نشأت حوله جميع معارف العرب التي جدت في حياتهم بعد الإسلام؛ حتى صح لنا ما أشرنا إليه.... من أن القرآن الكريم يشكل المصدر الأول للثقافة العربية الإسلامية؛ هذه الثقافة الغنية الواسعة التي آشتملت على على علوم القرآن

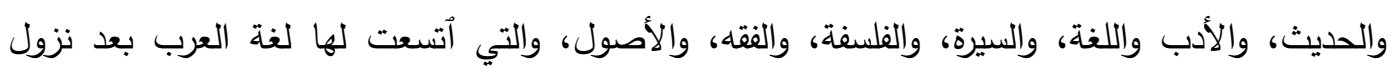
القرآن) لا ينتاب أحداً شك أو يساوره ريب في كون (اللغة العربية من أوسع اللغات، وأغناها، وأدقها تصويراً،

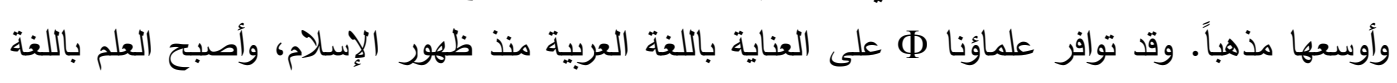

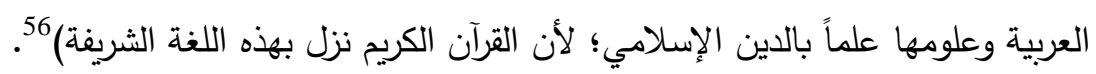

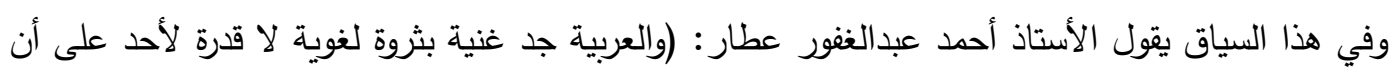

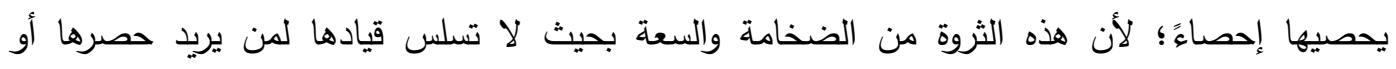

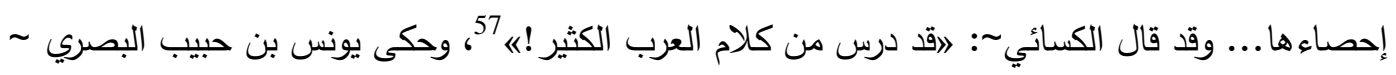

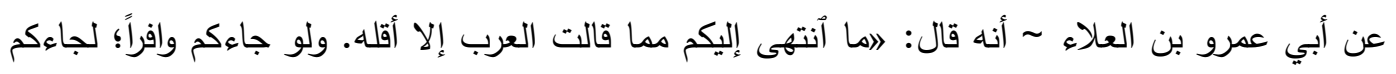
علم وشعر كثير!ه 58 وإن المستعمل من العربية في عصرنا الحاضر لا يزيد على عشرة آلاف مادة.

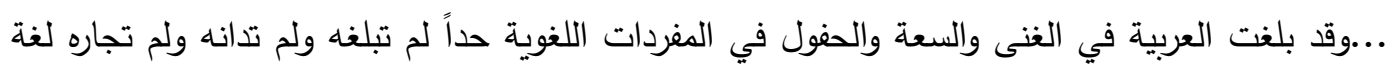
على وجه هذه البسيطة لغاية الآن. ومع أن ما يستعمل من ألفاظ اللغة لم يتجاوز عشرة الآلاف من المواد؛

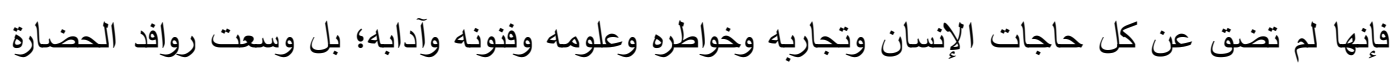

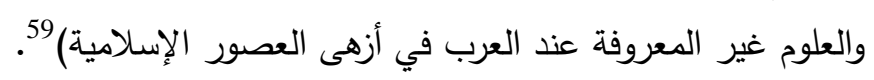

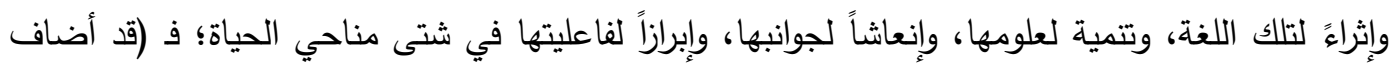
القرآن الكريم أنموذجاً للتعبير بالعربية لم تعرفه العربية من قبل، أنموذجاً له الخلود والبقاء لا لا تمساه يد

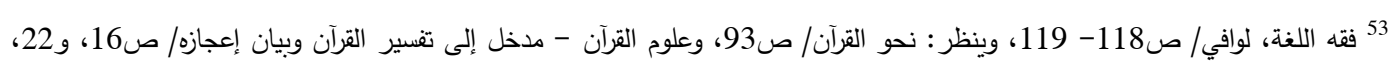

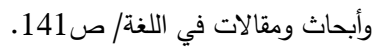

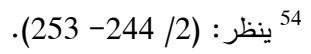

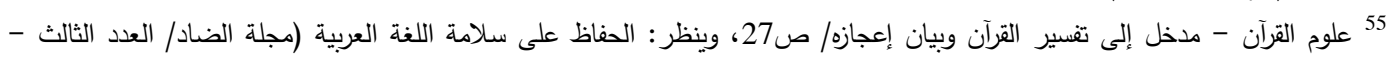

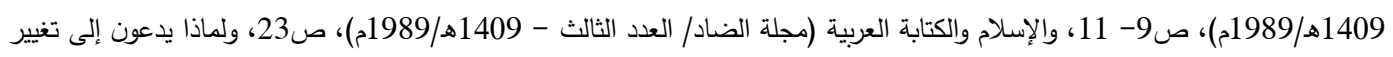

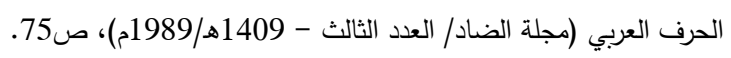

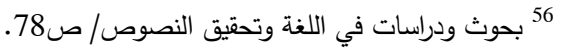

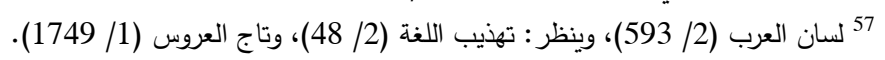

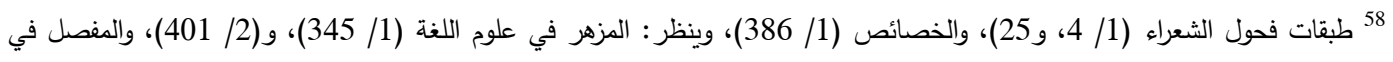

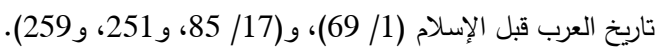
59

\section{IJHER}

International Journal of Humanities and Educational Research

Volume 2, Issue 4, December 2020, p.38-60 
التغيير والتحريف. لقد كانت العربية قبل نزول القرآن تصنف إلى شعر ونثر. فلما نزل القرآن؛ صارت

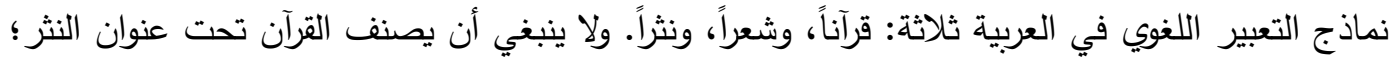

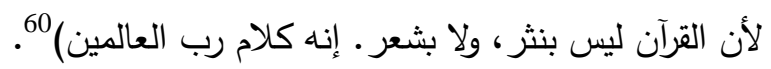

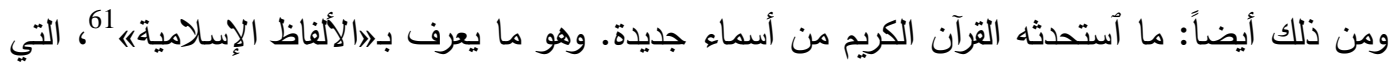
جاءت تعبيراً عن المعاني الإسلامية الجديدة التي لم يكن للعرب معرفة بها من قبل هذا؛ إذ (تقبلت العربية

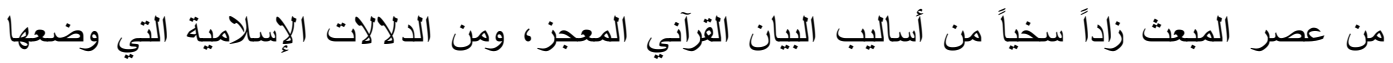

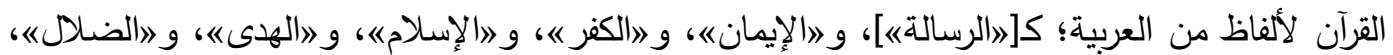

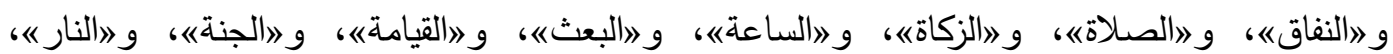

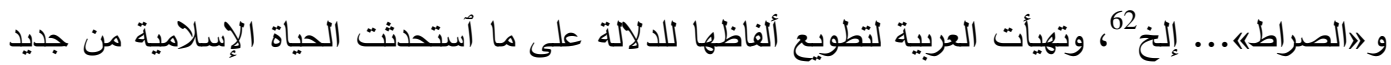

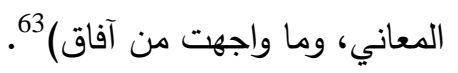

ويدخل في ذلك الباب أيضاً الألفاظ الاصطلاحية التي نشأت في رحاب العلوم الثرعية المرتبطة بالقرآن

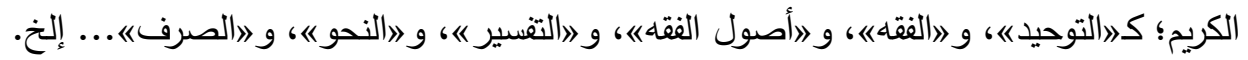

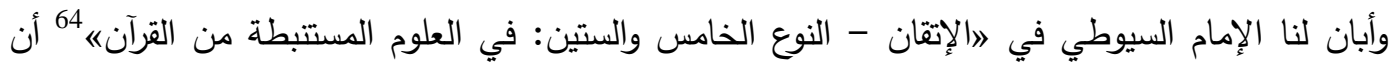
هنالك أكثر من ستين علماً من علوم العربية نشأت وشبت وترعرعت في رحاب القرآن الكريم؛ من أجل

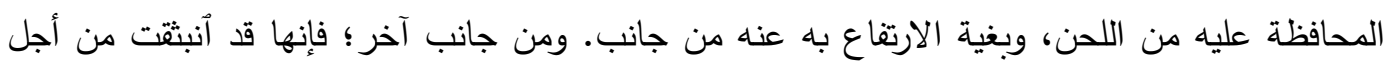
محاولة فهمه وإدراكه. وما دام ذلك كذلك؛ فلا مناص لنا ولا مفر من القول بأن القرآن قد غدا - بحق - السبب المباشر والرئيس

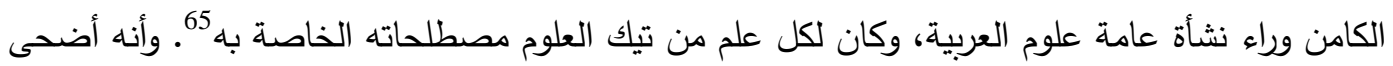

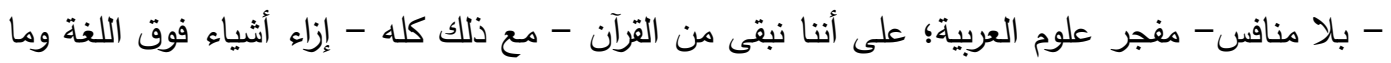
تعارف من قواعدها وآدابها66؛ إذ إن (في الكتاب العزيز أساليب وتراكيب لا يمكن أن يفي غيرها بمعناها)

وإذا كان ذلك كذلك؛ فلا بد من القيام الدائب على خدمة ذلك الكتاب الكريم، والدستور المنظم العظيم. ومن أجل خدمة القرآن الكريم، ومحاولة تيسير فهمه والنطق به على المسلمين من الأعاجم، ومن أجل صيانته

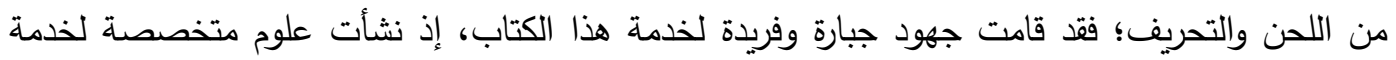

$$
\begin{aligned}
& 60 \text { (العربية وعلم اللغة الحديث/ ص36. }
\end{aligned}
$$

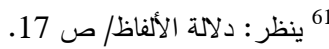

$$
\begin{aligned}
& 62 \text { تنظر الألفاظ الإسلامية في: الصاحبي/صنئ ص44 وما بعدها، والمزهر (1/ 294). }
\end{aligned}
$$

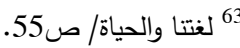

$$
\begin{aligned}
& \text { 64 ينظر : (244 244)، وما بعدها. }
\end{aligned}
$$

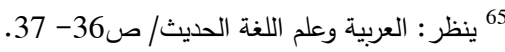

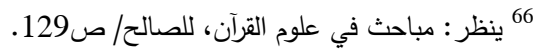

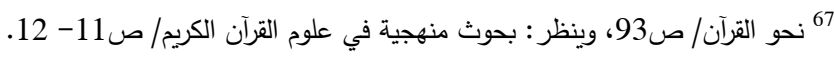

\section{IJHER}

International Journal of Humanities and Educational Research

Volume 2, Issue 4, December 2020, p.38-60 
القرآن المبين بشكل مباشر 68، من أبرزها 》علوم القرآنه بمعناها الجامع الثامل؛ لدراسة كل ما يتصل

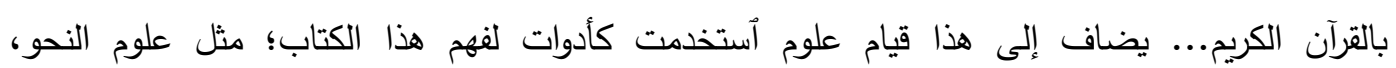

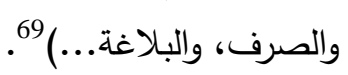

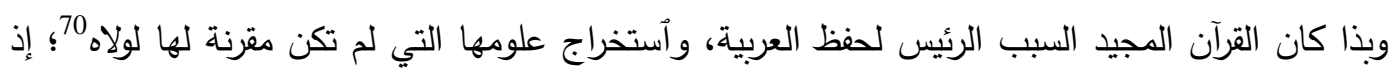
حظيت بفضل نزوله بها بمكان علي، وخطت (خطوات واسعة... فازدهرت ألفاظاً ودلالات وأساليب وصوراً،

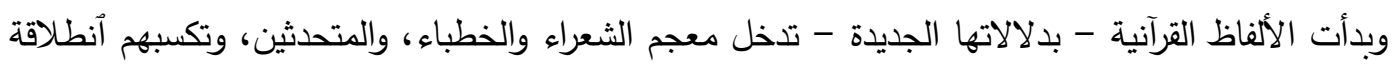

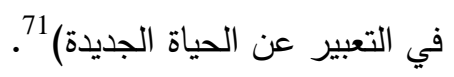

\section{توسيع نطاق أستعمال اللغة العربية}

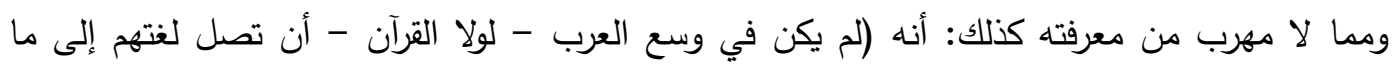

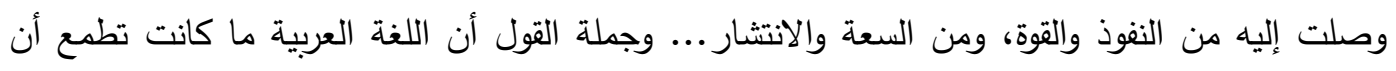

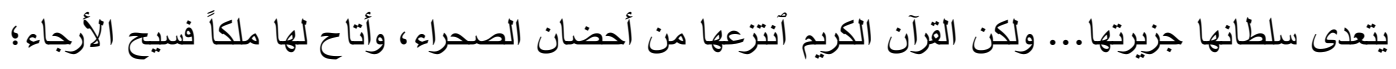

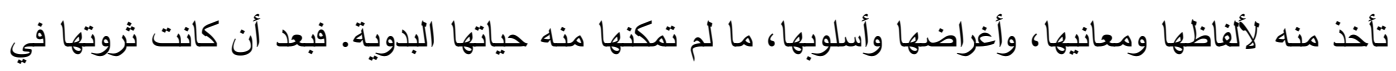

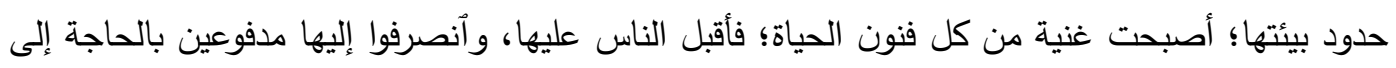

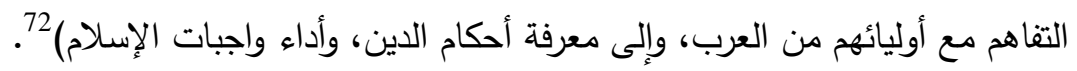

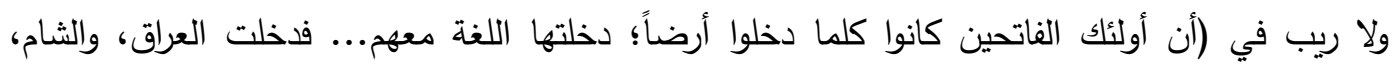

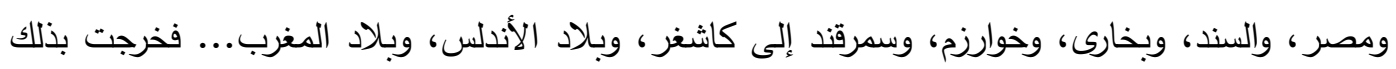

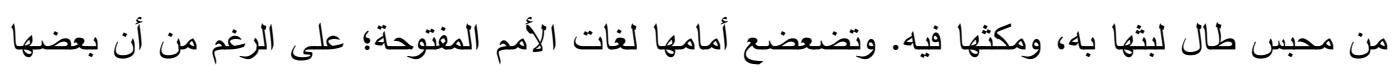

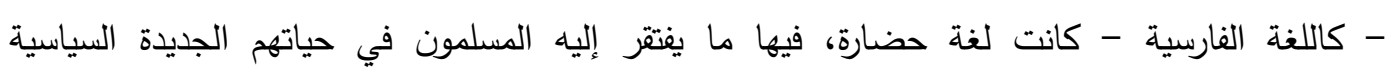
والاجتماعية؛ حتى لم تجرؤ لغة على الوقوف إلى جانبها، وبقيت هي اللغة الرسمية لسائر الممالك فئك الإسلامية)

ومما يجدر أن لا يعزب عن بال أحدنا أيضاً العلم بأن (اللغة العربية قبل نزول القرآن الكريم وبعده كانت

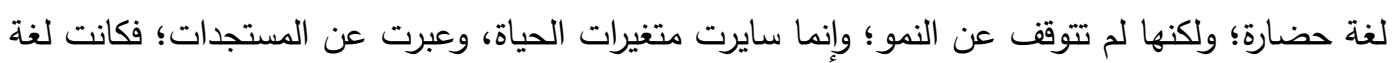

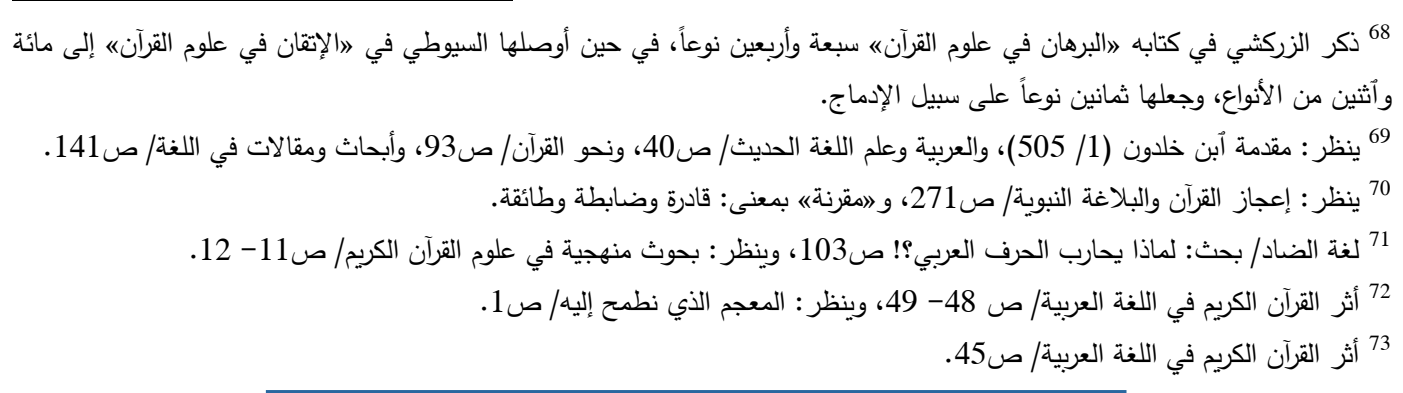

\section{IJHER}

International Journal of Humanities and Educational Research

Volume 2, Issue 4, December 2020, p.38-60 
السياسة، والاقتصاد، والاجتماع، كما كانت لغة الآداب والعلوم والفنون. وقد وضعت بها المصنفات،

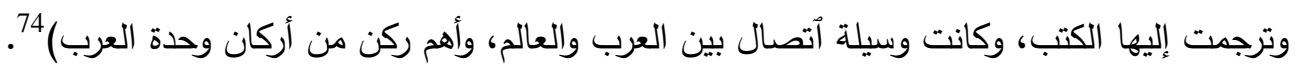
ومن أجلِّ المظاهر الأخرى لارتباط العربية بالقرآن الكريم: ذلك الحدث الجسيم، والتطور الجلل الذي طرأ ولتها

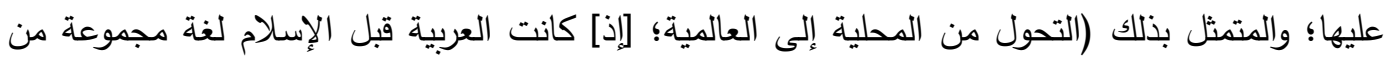

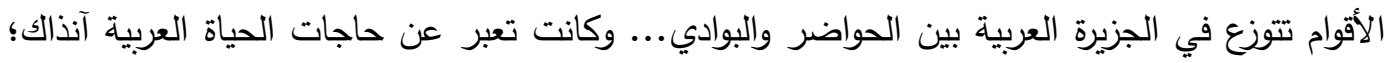

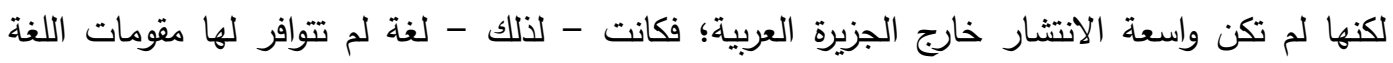
العالمية. وأنتقلت العربية بعد الإسلام إلى لغة عالمية بكل معنى الكلمة الكئ فكان يحرص على تعلى تعلها

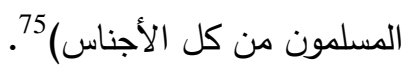

ومن أجل ذلك الكتاب الكريم، وبفضل معجزته الخالدة؛ (يرجى أن تكون هذه اللغة بعد قرن من الزمان لغة الملايين ممن لم يتكلموها حتى الآن. وفي طليعتهم أهل الهند، والملايو المسلمون، ومعهم في آسيا وأفريقيا

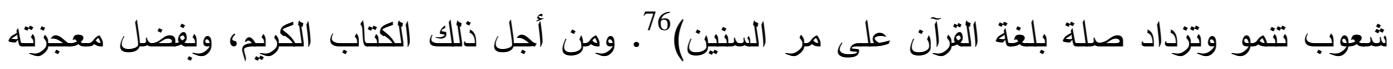

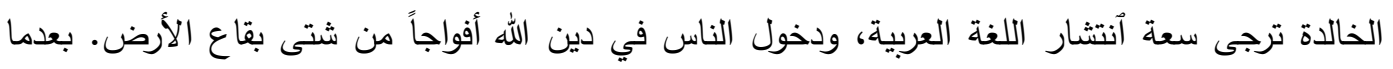

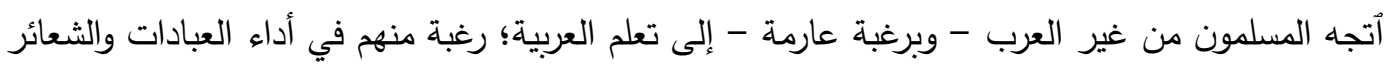

الدينية، وتلاوة القرآن؛ لذا فقد اُنتشرت اللغة العربية أنتشاراً ما كان ليتحقق لها لولا القرآن الكريم 77.

\section{آثار أخرى للقرآن الكريم في اللغة العربية}

إن تأثير القرآن الكريم في اللغة العربية لم يقتصر على الجوانب التي مرت معنا آنفاً، وإنما تعدى تأثيره ما

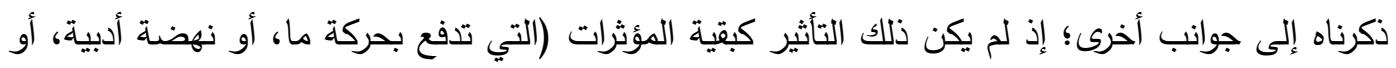
علمية، أو فنية، لفترة من الفترات، أو حقبة من الحقب، ثم تختفي وتزول بزوال المؤثر، أو بانتهاء الظرف

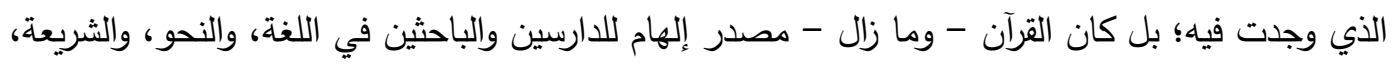

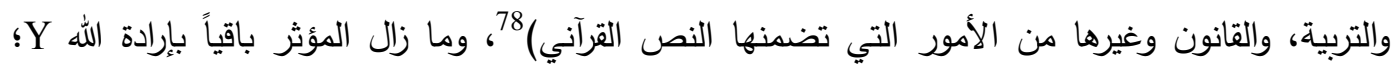

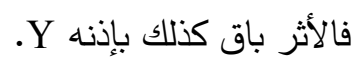
وكأي من حال؛ فإن العناية بأمر اللغة كانت جزءاً من التغيير الشامل الذي أحدثه الإسلام في حياة العرب.

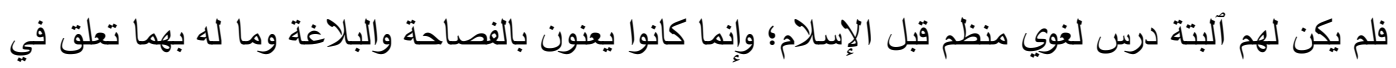

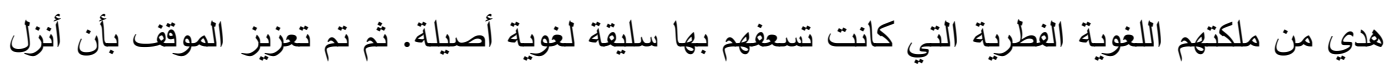
القرآن الكريم بلغتهم؛ فكان أول كتاب مدون تشهده العربية.

$$
\begin{aligned}
& \text { 75 لغة الضاد/ بحث: لماذا يحارب الحرف العربي؟! ص101. }
\end{aligned}
$$

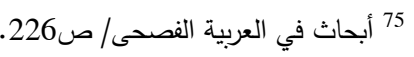

$$
\begin{aligned}
& 76 \text { القرآن الكريم وأثره في الدراسات النحوية/226 صفحة "احي" من المقدمة. }
\end{aligned}
$$

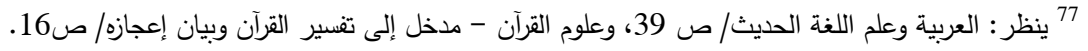

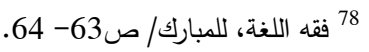

\section{IJHER}

International Journal of Humanities and Educational Research

Volume 2, Issue 4, December 2020, p.38-60 
وتعد الجهود التي بذلها المسلمون الأوائل في مجال قراءة القرآن الكريم وكتابته بداية للدرس اللغوي العربي؛

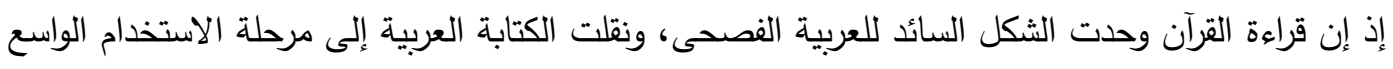

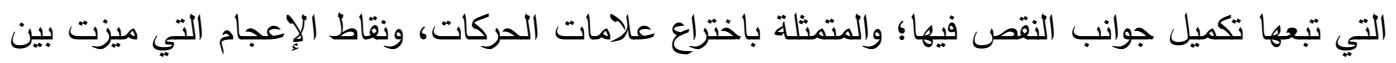

$$
\text { الحروف المتماثلة في الصورة }
$$

ومن مظاهر تأثر العربية بالقرآن الكريم وأرتباطها الوثيق به: ذلك (التحول من التغير إلى الثبات؛ [إذ]

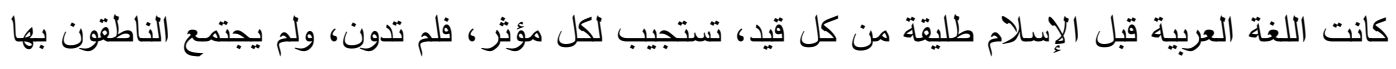

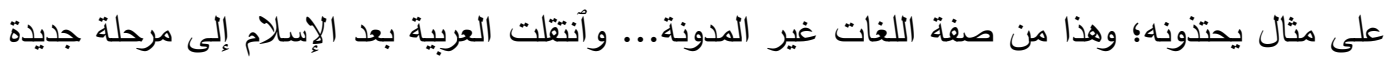

من الثبات والاستقرار ، تتناسب ودورها الحضاري الجديد الذي منحها إياه الدين الإسلامي....

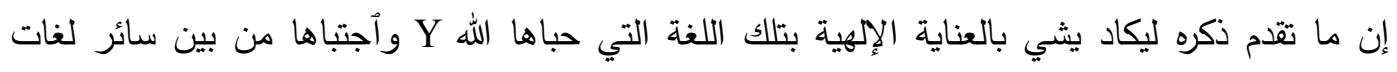

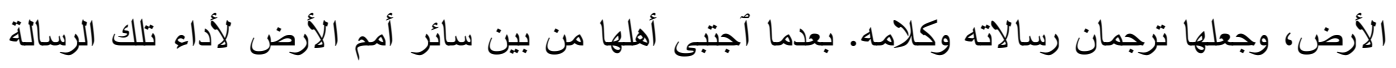

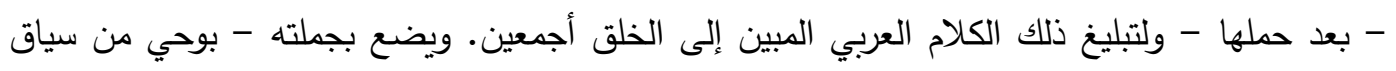

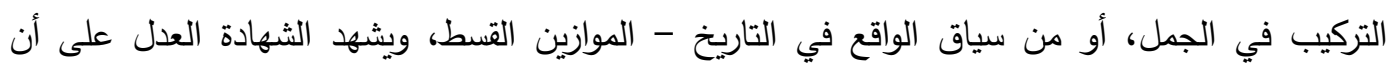
(للحدث القرآني تأثيره العظيم في العربية ودفعها خطوات فسيحة إلى الأمام. فقد عملت لغة التتزيل على ولى

$$
\text { توحيد هذه اللغة) } 81 .
$$

لقد حوى القرآن الكريم - كتاب الإسلام والعربية الأكبر - بين دفتيه من الأسرار الكامنة، والعلوم الكاملة، والأفانين المختلفة لتلك اللغة المجتباة، ومن عوامل بقائها، ومقومات نجاحها وأستمرارها ومضيها قدماً غرائب نكت يلطف مدركها، ومستودعات أسرار يدق مسلكها، وحقائق آداب لا يرتجى الوقوف على ماهية كنها، وفرائد حكم كامنة، وقلائد درر منظومة تملك بحق على طلابها من عباد الله العلماء الأفئدة والألباب!

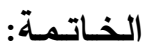

وفي ختام بحثي عن آثار القرآن الكريم وما أحدثه في اللغة العربية، والتي أفضت إلى سيادتها؛ لا يسعني

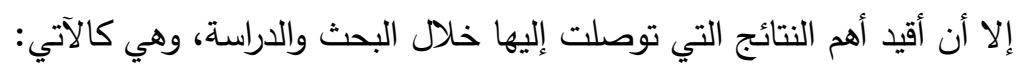

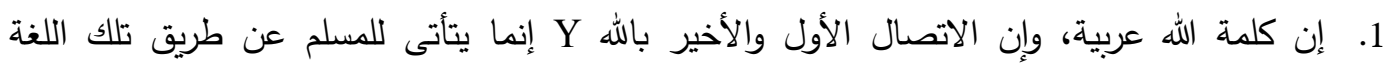
الكريمة، يعرف من خلالها ما عليه من أعمال وواجبات، وما له من حقوق واُمتيازات؛ فاللغة - إذاً هي مركز الاتصال والتلاقي بين الخالق والمخلوق، وهي المفتاح لفهم حقيقة هذا الوجود، ومعرفة المزيد عما ينتظره ويلوح في أفقه من الموت، والبرزخ، والبعث والنشور !.

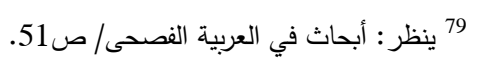

80 أبحاث في العربية الفصحى/ 225- 226، وأبحاث ومعالات في اللغة/ ص141، وينظر : فقه اللغة وسر العربية/ص1، ولغة الضاد/

ص90. 81 دراسات في اللغة/ص194، وفقه اللغة المقارن/ص232، وينظر : علوم القرآن - مدخل إلى تغسير القرآن وبيان إعجاز/ص24.

\section{IJHER}

International Journal of Humanities and Educational Research

Volume 2, Issue 4, December 2020, p.38-60 
2. ما كانت لغة هذا الكتاب المبين 》العربيةه تطمع في أن يتعدى سلطانها جزيرتها؛ ولكن القرآن الكريم

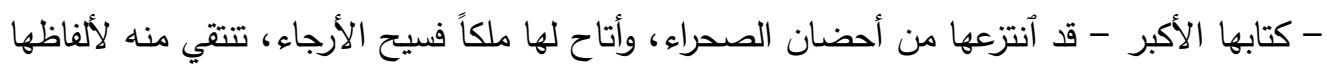

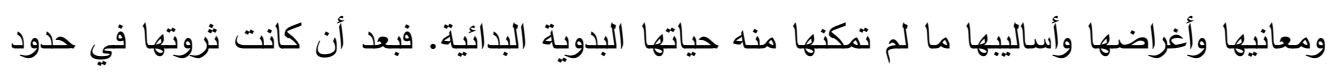

$$
\text { بيئتها؛ غدت غنية في كل فنون الحياة. }
$$

3. ليس في هذه الأرض أمة كانت تربيتها لغوية غير أهل هذه الجزيرة، فما كان فيهخ كالبيان آنق منظراً،

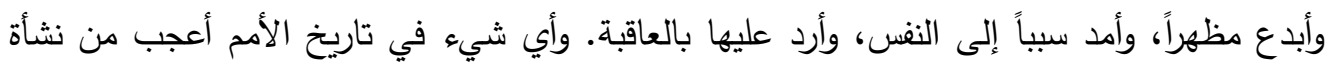

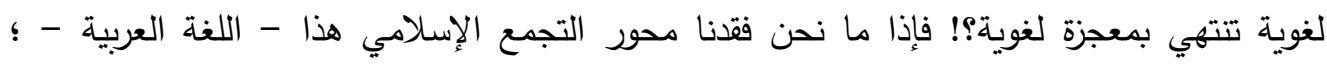

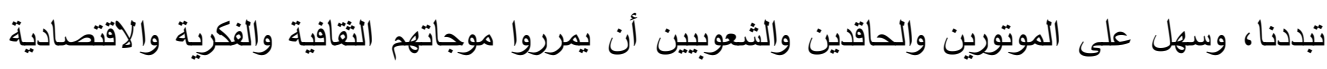

$$
\text { لتطوينا وتبتلعنا زرافات ووحدانا! وسئ. }
$$

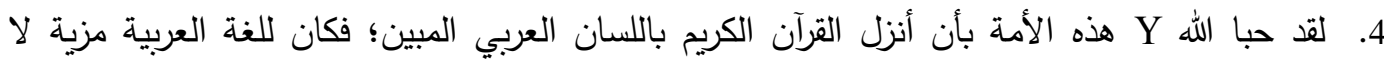
تتأتى للغة سواها. وكما أثر القرآن الكريم في الأمة العربية: في أخلاقها، وعقيدتها، وتعاملاتها، وشتى باته

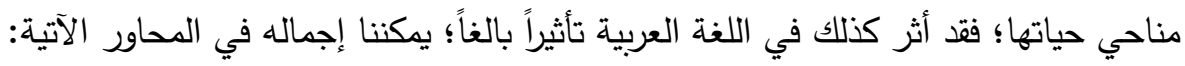

$$
\begin{aligned}
& \text { - - الحفاظ على اللغة العربية من الاندراس والضياع والفناء. } \\
& \text { تهذيب اللغة العربية والسمو بها. } \\
& \text { توسيع جوانب اللغة العربية. } \\
& \text { توسيع نطاق أستعمال اللغة العربية. }
\end{aligned}
$$

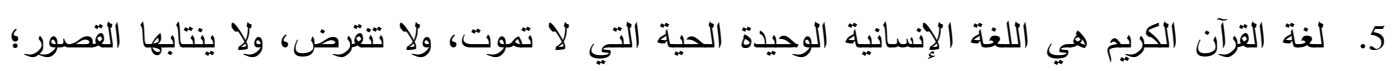
وذلك لأنها مرتبطة بكتاب سماوي مقدس، وسر ذلك أنه ما دام مسلم على وجه هذه المعمورة يتعبد

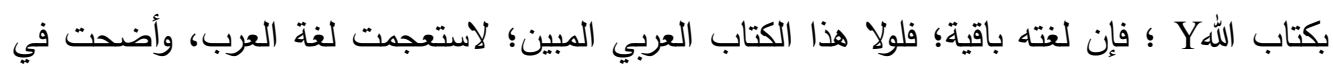

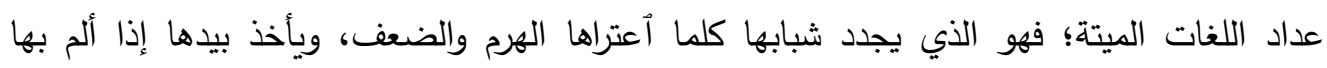
التخلف والركود.

6. لد تسنت للعربية الفصحى ظروف خاصة لم تتوافر لأي من لغات العالم جمع؛ ذلك لأنها أرتبطت

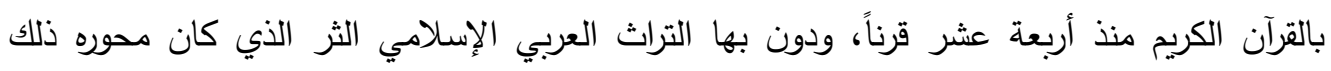
الكتاب العزيز في كثير من مظاهره. وقد تكفل الله Y بحفظها ما دام يحفظ دينه وكتابه. 7. لقد كان لكتاب الله Y أبلغ الأثر في أن أستعصت العربية على الغزو الفكري واللغوي المتتابع، وتجاوزت شتى الانكسارات في الحضارة العربية الإسلامية، وبقيت ما بقي كتاب الله Y يتلى في الغدو والآصال.

8. لولا أن شرَّف الله Y تلك اللغة؛ فأنزل بها كتابه، وقيض له من خلقه من يتلوه صباح مساء، ووعد

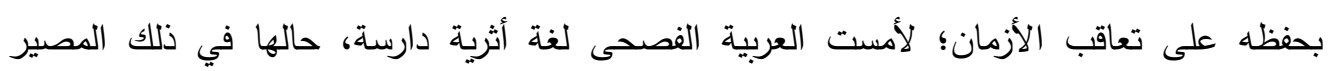


المأساوي كحال لغات العالم الأخرى التي لم تتسن لها، ولم تتهياً عوامل الحفظ والمنعة؛ كاللاتينية، أو السنسكريتية.

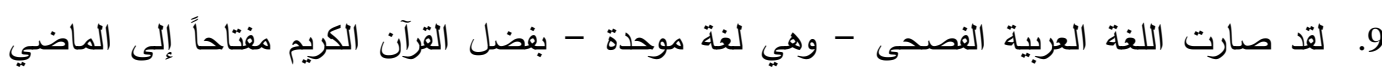

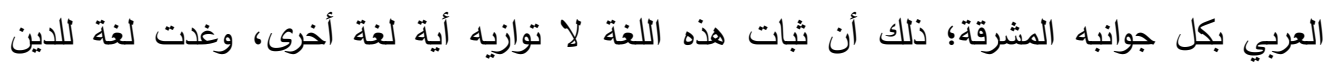

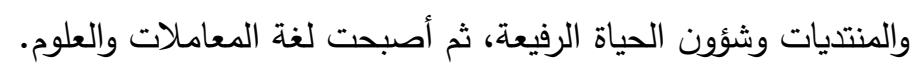

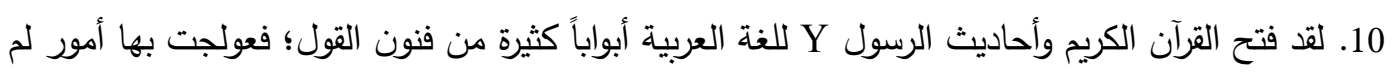

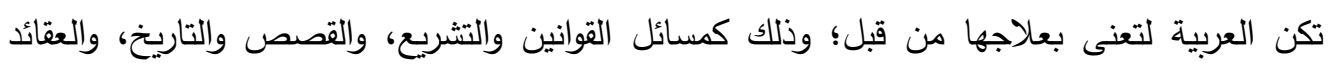

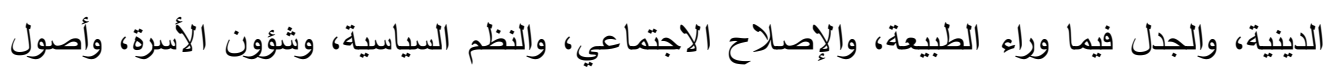

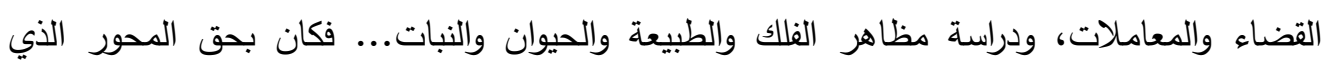

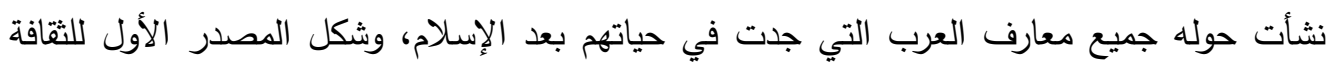
العربية الإسلامية.

11. لقد أقام القرآن الكريم للعرب جامعة تم من خلالها توحيدهم تحت لوائه، يسيرون على منواله، ويتيأون

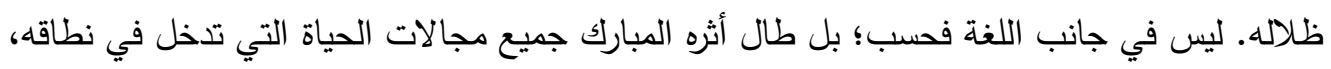

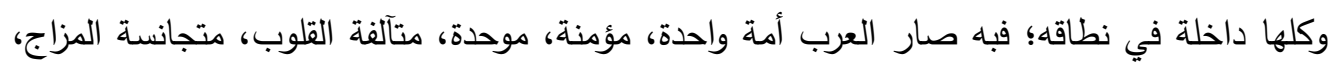

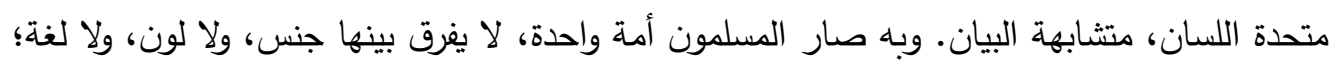
فقد أنصهرت كل هذه الفوارق في نور الإسلام، ولم يبق إلا الاعتزاز بالإن الإسلام والقرآن.

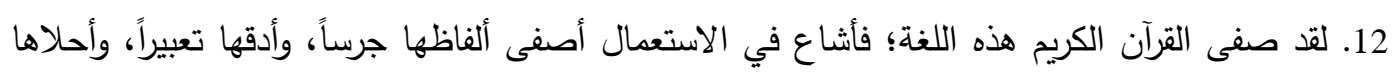

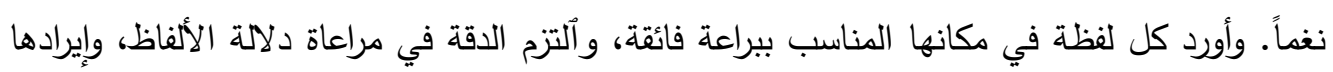

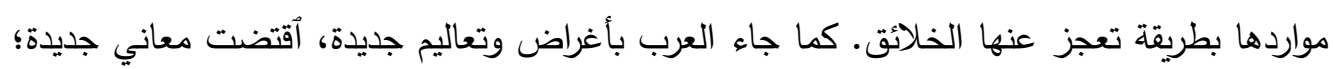

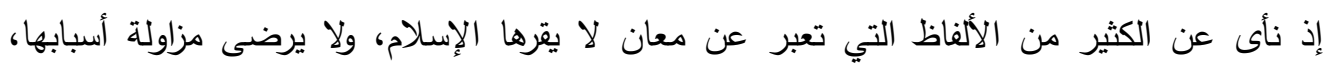
والوقوع في آثارها.

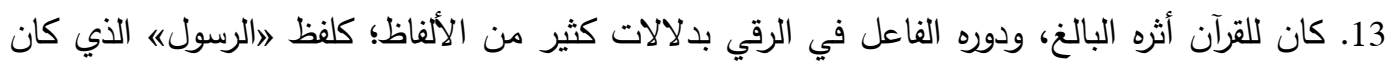

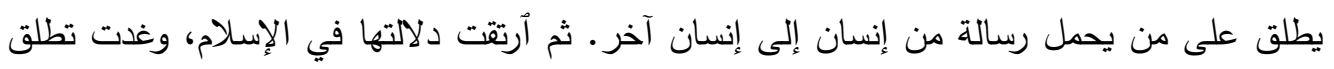

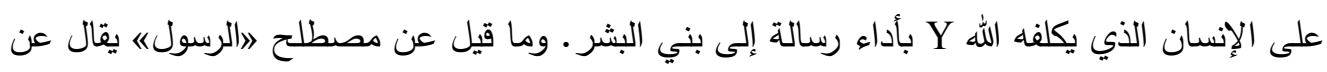
غيره من الألفاظ كثير.

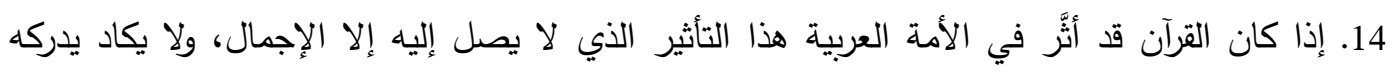

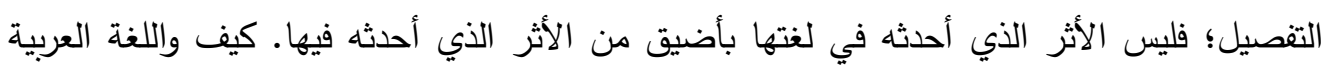

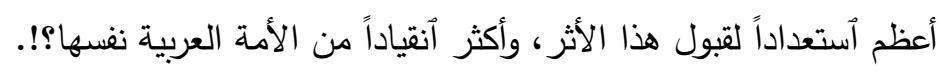

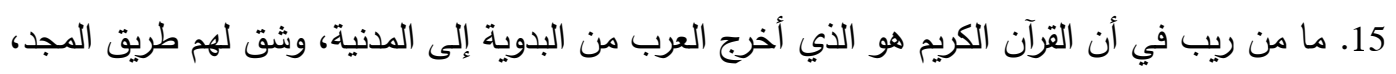

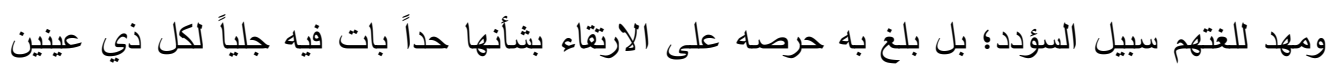

\section{IJHER}

International Journal of Humanities and Educational Research

Volume 2, Issue 4, December 2020, p.38-60 
مقدار الحفاوة بتلك اللغة المجتباة. فما أن بزغت شمس الإسلام من سماء القرآن؛ حتى أكتسبت العربية قوة في البيان، وجزالة في اللفظ، وفخامة في المعنى؛ بما تشتمل عليه من ألفاظ موحية، وكلمات

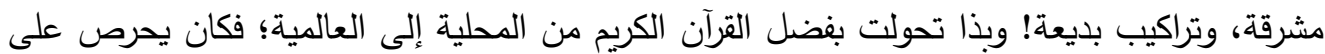
تعلمها المسلمون من كل الأجناس.

16. من أجل ذلك الكتاب الكريم، وبفضل معجزته الخالدة؛ يرجى أن تكون هذه اللغة بعد قرن من الزمان لغة الملايين ممن لم يتكلموها حتى الآن. وفي طليعتهم أهل الهند، والملايو المسلمون، ومعهم في آسيا وأفريقيا شعوب تتمو وتزداد صلة بلغة القرآن على مر السنين. ومن أجل ذلك الكتاب الكريم، وبفضل

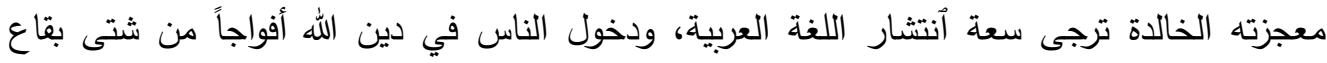

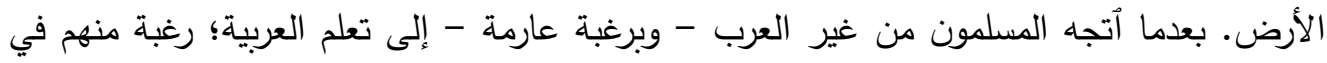
أداء العبادات والثعائر الدينية، وتلاوة القرآن.

17. من أهم مظاهر أثر القرآن الكريم في اللغة العربية: التحول من الرواية الثفوية إلى التدوين والتقعيد؛ إذ إذان

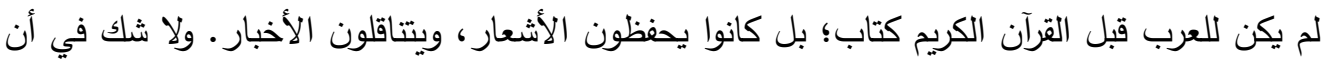
الحضارة لا تبنى على الرواية الثفوية، والعلوم لا بد لها من التدوين. وقد تحولت الأمة بفضل القرآن

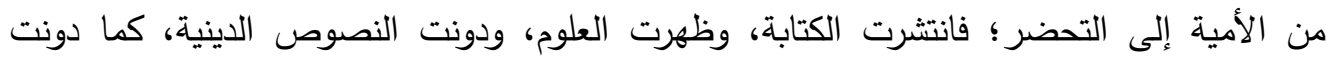
النصوص الأدبية. والتدوين من لوازم حيوية اللغة وديمومتها.

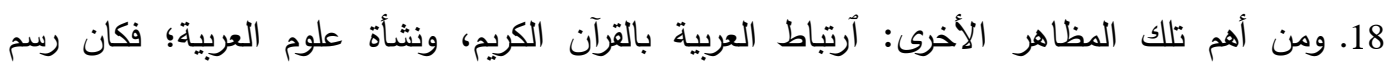

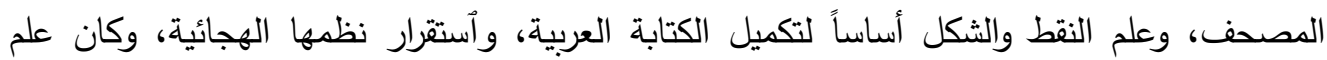
التجويد والقراءات أساساً لعلم الأصوات اللغوية وضبط النطق العربي، وكان علم النحو والصرف لتحفي يستجيب لحاجة الدارسين للبناء اللغوي للقرآن الكريم، كما كان علم التفسير والمؤلفات في معاني القرآن رافداً كبيراً في المعجم العربي.

19. ومن مظاهر تأثر العربية بالقرآن الكريم واُرتباطها الوثيق به: التحول من التغير إلى الثبات؛ إذ كانت

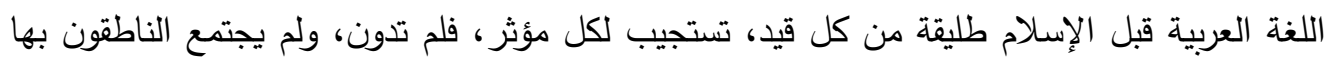

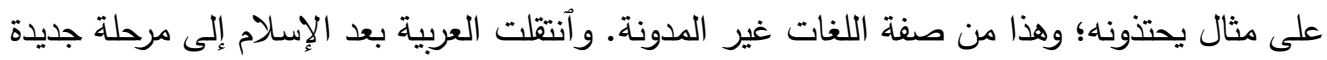
من الثبات والاستقرار ، تتاسب ودورها الحضاري الجديد الذي منحها إياه الدين الإسلامي.

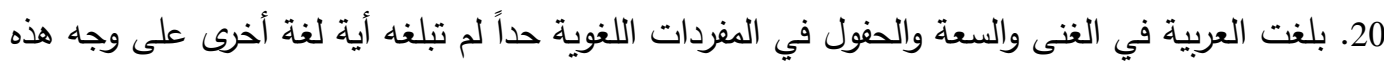

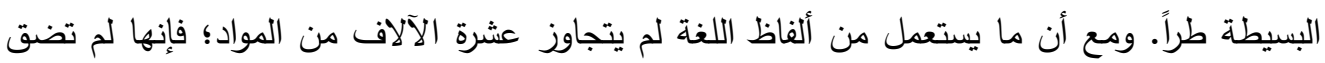

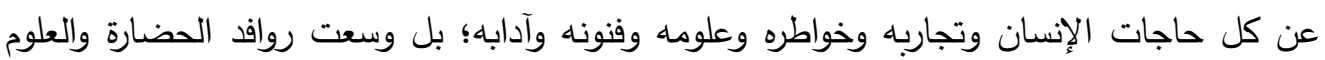
غير المعروفة عند العرب في أزهى العصور الإسلامية. 21. كانت اللغة العربية قبل نزول القرآن الكريم وبعده لغة حضارة؛ ولكنها لم تتوقف عن النموبه النهو؛ وإنما

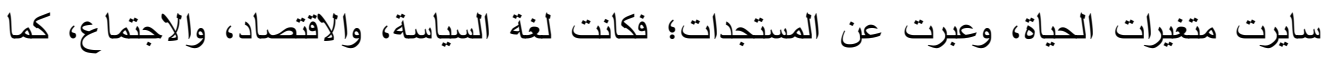

\section{IJHER}

International Journal of Humanities and Educational Research

Volume 2, Issue 4, December 2020, p.38-60 
كانت لغة الآداب والعلوم والفنون. وقد وضعت بها المصنفات، وترجمت إليها الكتب، وكانت وسيلة

$$
\text { أتصال بين العرب والعالم، وأهم ركن من أركان وحدة العرب. }
$$

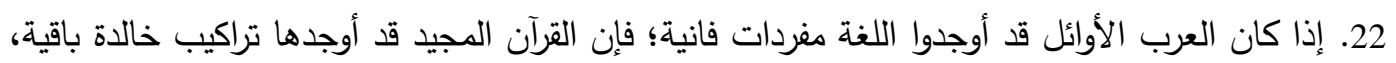

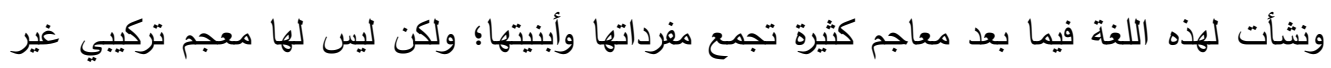

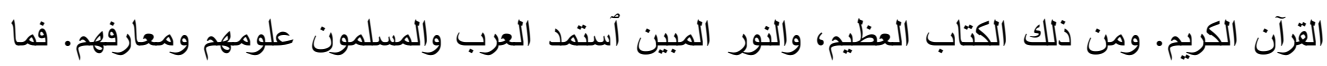

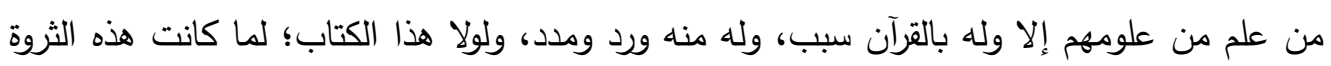
الطائلة من العلوم التي تدور حول القرآن ولغة القرآن، وتجول في رحابه ولابه الواسعة. 23. لقد توافر علماؤنا ه على العناية باللغة العربية منذ ظهور الإسلام، وأصبح العلم باللغة العربية

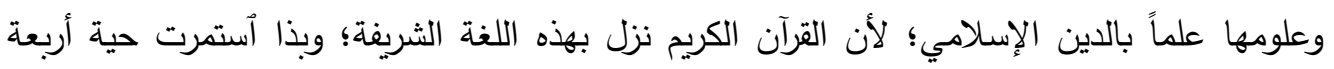

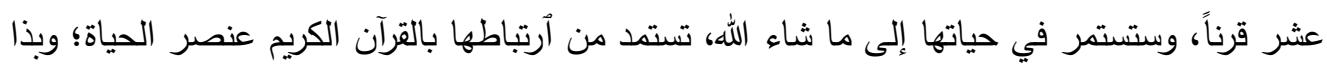

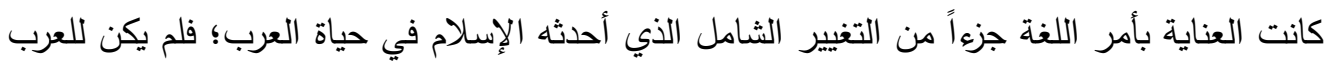

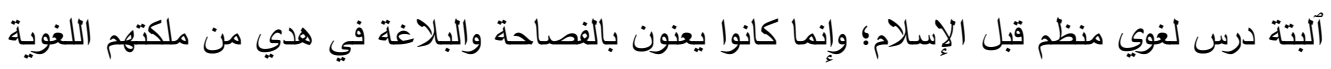

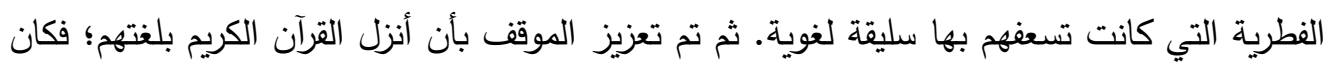

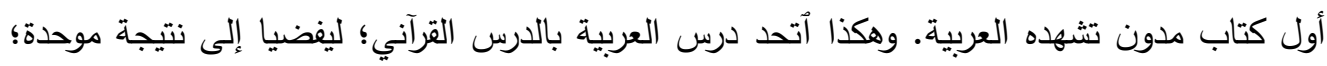
هي سلامة النطق، وسلامة التفكير • 24. كان القرآن الكريم محوراً لجمع الدراسات العربية التي قامت في الأساس لخدمته، ومن بينها الدراسات اللغوية. ولولاه لاندثرت اللغة العربية الفصحى، وأصبحت لغة الغربة أثرية تشبه اللاتينية، والسنسكريتية.

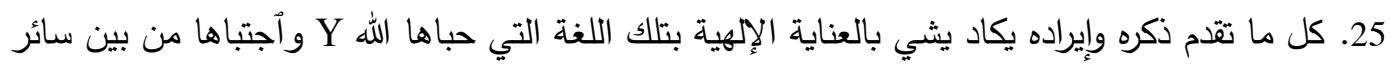
لغات الأرض، وجعلها ترجمان رسالاته وكلامه. بعدما آجتبى أهلها من بين سائر أمم الأرض لألداء ألاء تلك الرسالة - بعد حملها - ولتبليغ ذلك الكلام العربي المبين إلى الخلق أجمعين.

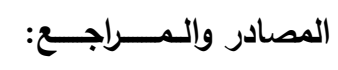

القرآن الكريم.

أبحاث في العربية الفصحى: أ. د. غانم قدوري الحمد/ دار عمار (عمان)، ط1، 1426هـ/ 2005م.

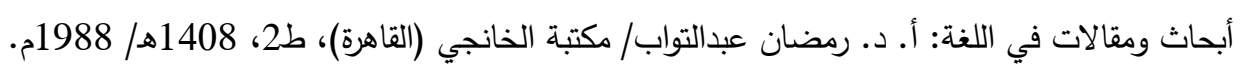

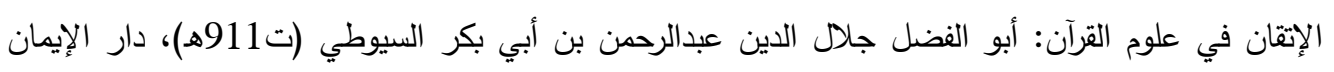

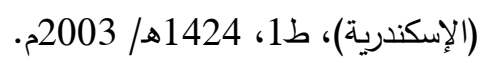

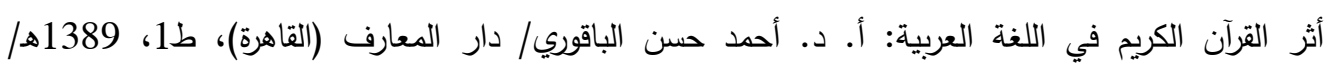
1969م أزمة التعبير الأدبي بين العامية والفصحى: إبراهيم بن إسماعيل الإبياري، وإبراهيم محمود رضوان/ دار المعرفة

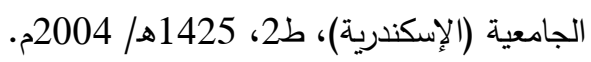

\section{IJHER}

International Journal of Humanities and Educational Research

Volume 2, Issue 4, December 2020, p.38-60 
الإسلام والكتابة العربية: أ. د. حسام سعيد النعيمي/ بحث منشور في مجلة 》الضاده، (ج3)، ذو الحجة

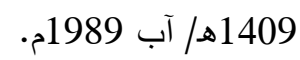

إعجاز القرآن والبلاغة النبوية: الأستاذ مصطفى صادق الرافعي/ مراجعة وضبط: الأستاذ محمد سعيد العريان/

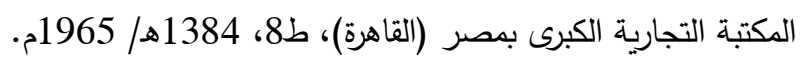
بحوث منهجية في علوم القرآن الكريم: موسى إبراهيم الإبراهيم/ دار عمار (عمان)، ط2، 1416 148ه/ 1966 1996م.

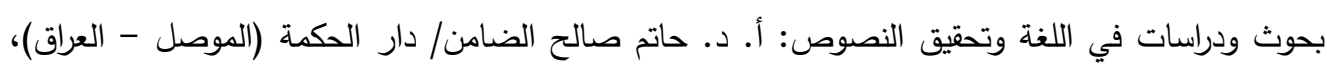

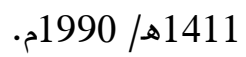
البرهان في علوم القرآن: أبو عبدالله بدر الدين تحمح بن محمد بن بهادر بن عبدالله الزركثي (ت794هـ)، تقديم

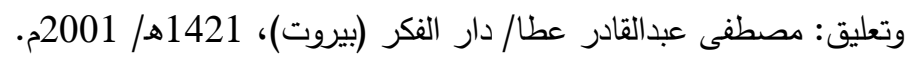

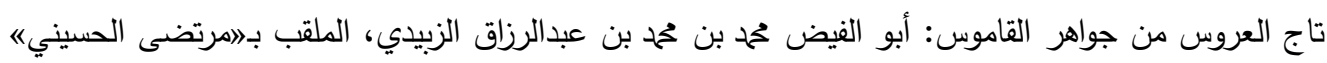

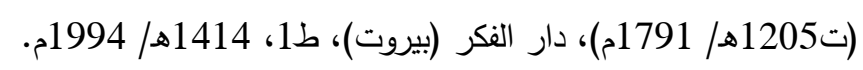

تاريخ آداب العرب: الأستاذ مصطفى صادق الرافعي/ دار الكتاب العببي (بيروت)، ط201، 1414، 1394هـ/ 1974م.

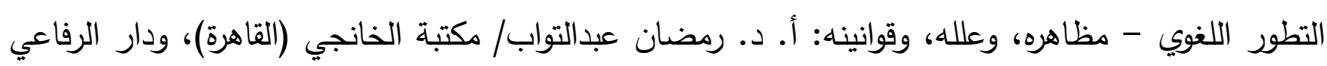

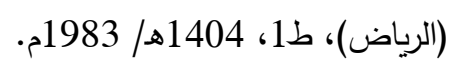

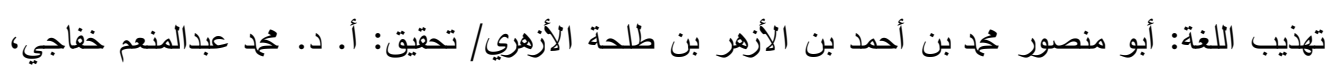

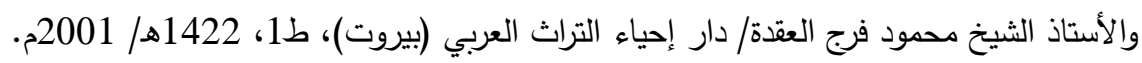

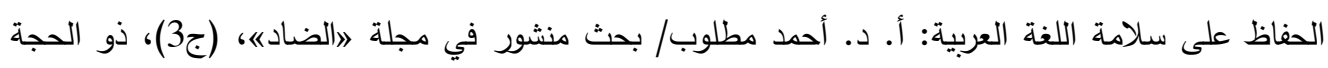

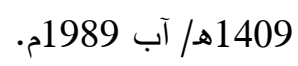
الخصائص: أبو الفتح عثمان بن جني الموصلي، النحوي (ت392هـ)، تحقيق: الثيخ ححم علي النجار/ دار الكتب (القاهرة)، 1371هـ الغون.

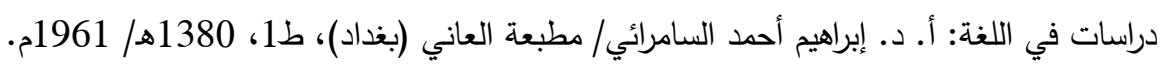

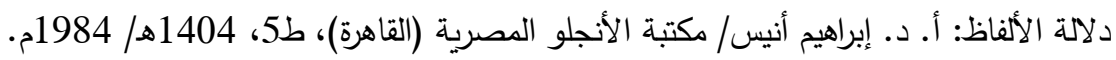

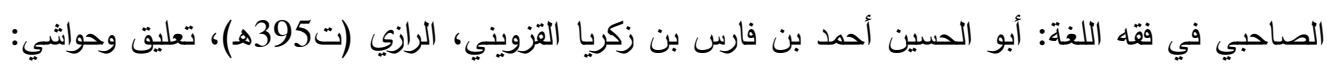

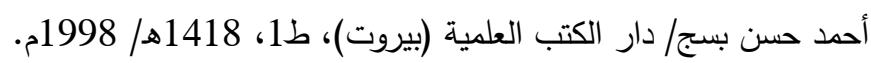

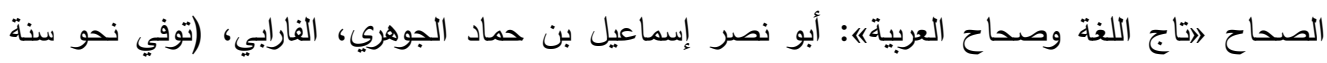

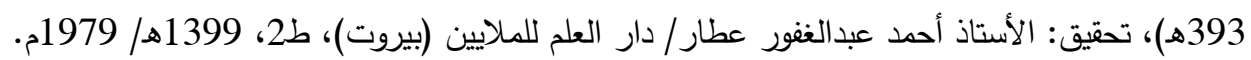

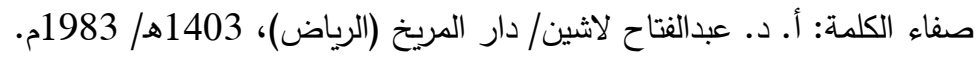

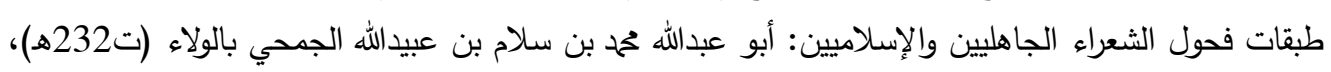

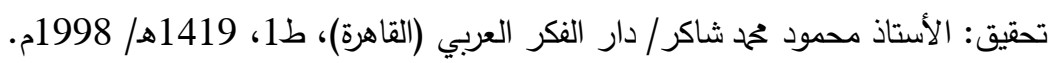

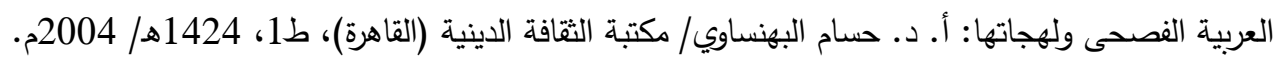

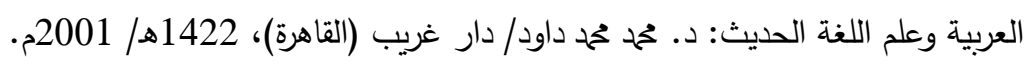

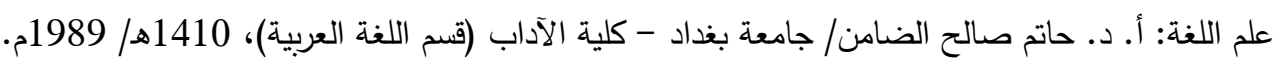

\section{IJHER}

International Journal of Humanities and Educational Research

Volume 2, Issue 4, December 2020, p.38-60 
علوم القرآن - مدخل إلى تفسير القرآن وبيان إعجازه: أ. د. عدنان محم زرزود/ الدكتب الإسلامي (بيروت)،

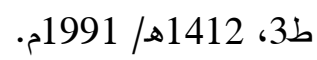

الفصحى لغة القرآن: الأستاذ أحمد أنور سيد أحمد الجندي/ دار المعرفة الجامعية (الإسكندرية)، ط2، 1427هـ/ 2006 فصول في فقه العربية: أ. د. رمضان عبدالتواب/ دار الجيل (القاهرة)، ط2، 1400هـ/ 1980م.

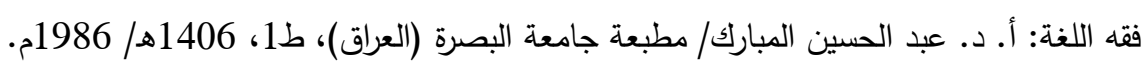

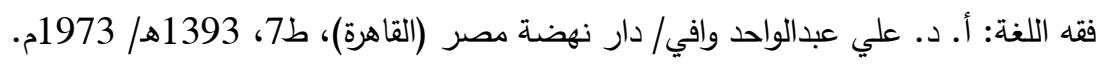

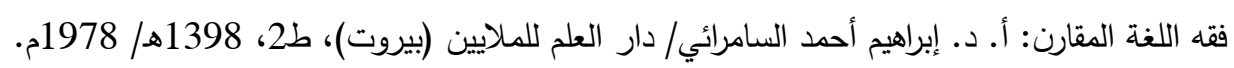

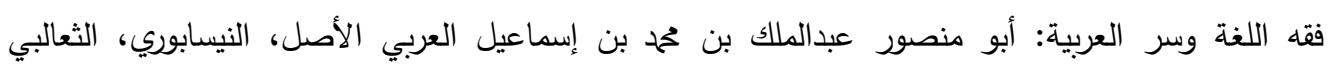

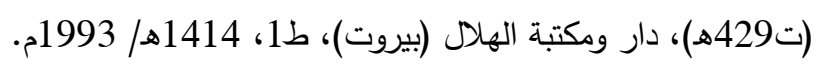

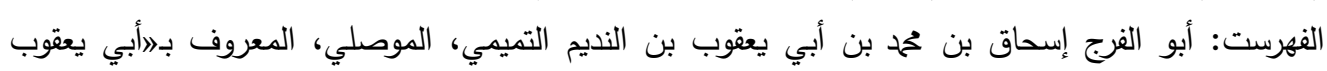

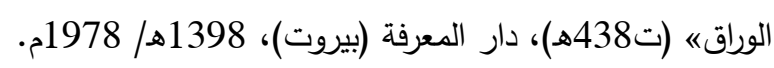
قال غير العرب عن العربية: مجموعة بحوث حول القرآن الكريم واللغة العببية/ منشورة في موقع الدكتبة الثاملة على شبكة الإنترنت. القرآن الكريم وأثره في الدراسات النحوية: أ. د. عبدالعال سالم مكرم/ مؤسسة علي جراح الصباح (الكويت)،

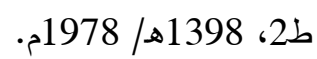
لسان العرب: أبو الفضل جمال الدين محمد بن جلال الدين مكرم بن منظور الإفريقي، المصري (ت71398هـ)، دار

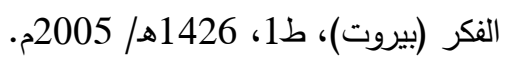
اللسان العربي مظهر لغوي للمعجز الإلهية الخالدة \القرآن الكريمه: أ. د. هادي نهر لعيبي/ بحث منشور في

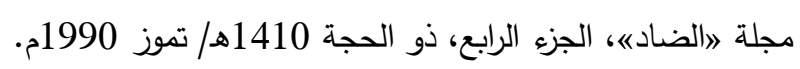
لغة الضاد الوقائع ندوة دائرة علوم اللغة العربية بيوم الضاد 1997مهادية إصداد الصدار : المجمع العلمي العراقي (بغداد

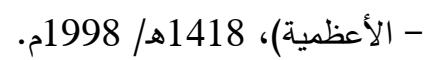
اللغة العربية: د. نذير حمدان/ مؤسسة شباب الجامعة (الإسكندرية)، ط2، 1423هـ/ 2002م.

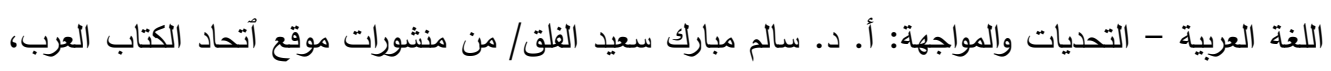

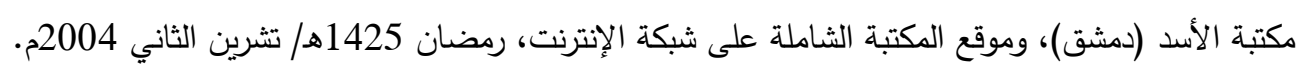

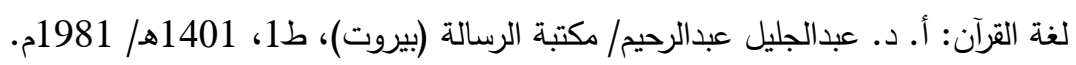

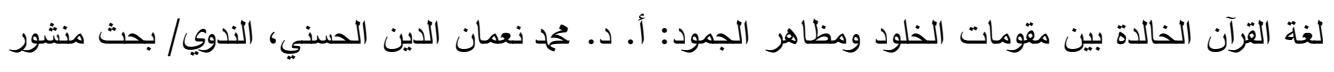

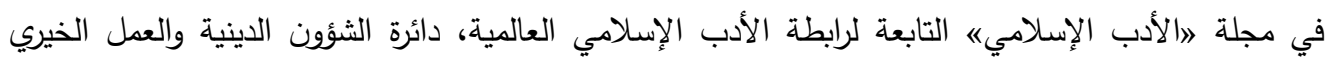

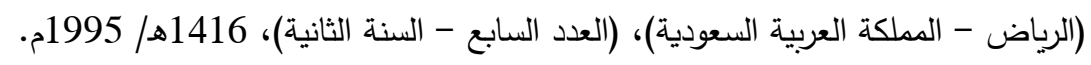

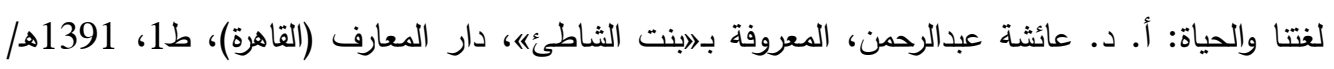
1971 لماذا يدعون إلى تغيير الحرف العببي! أ. د. رشيد عبدالرحمن العبيدي/ بحث منشور في مجلة \الضاده،؛

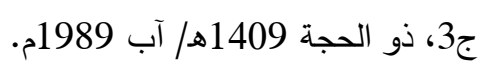

\section{IJHER}

International Journal of Humanities and Educational Research

Volume 2, Issue 4, December 2020, p.38-60 
مباحث في علوم القرآن: أ. د. صبحي الصالح/ دار العلم للملايين (بيروت)، ط18، 1411هـ/ 1991م.

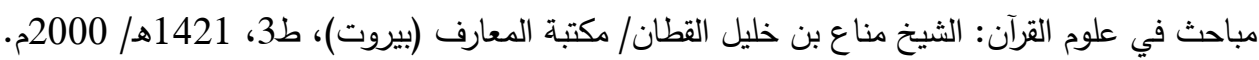
مجلة الضاد: تصدر عن الهيئة العليا للعناية باللغة العربية في جمهورية العراق (بغداد)، رئيس التحرير : أ. د. د.

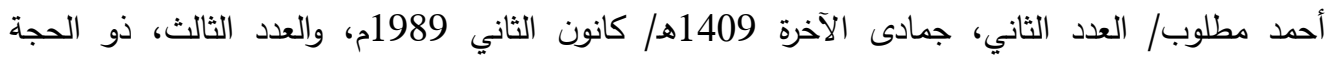

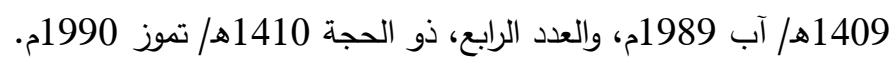

المدخل لدراسة القرآن الكريم: أ. د. محمد بن محمد بن سويلم أبو شهبة/ مكتبة السنة (القاهرة)، ط1، 1409، 1412هـ/ 1992 المزهر في علوم اللغة وأنواعها: أبو الفضل جلال الدين عبدالرحمن بن أبي بكر السيوطي (ت 911هـ)، شرح

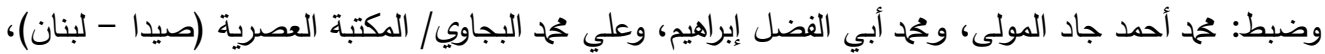

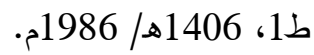

المشترك اللغوي - نظرية وتطبيقاً: أ. د. توفيق محم شاهين/ مكتبة وهبة (القاهرة)، ط1، 1400هـ/ 1400/ 1980م.

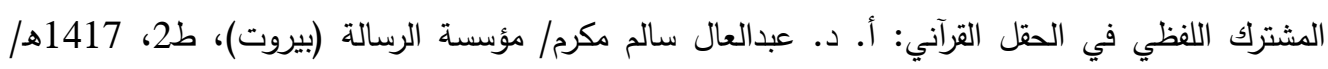
1996 الدعجم العربي - نثأته وتطوره: أ. د. حسين محم نصار/ دار مصر للطباعة (القاهرة)، ط4، 1408هـ/ 1988

المعجم الذي نطمح إليه: الشيخ محم حسن آل ياسين الخزرجي، النجفي/ المجمع العلمي العراقي (بغداد الأعظمية)، 1412هـ/ 1992م.

مقدمة أبن خلدون: أبو زيد ولي الدين عبدالرحمن بن حمح بن حمحد بن خلدون الحضرمي الأصل، التونسي المولد،

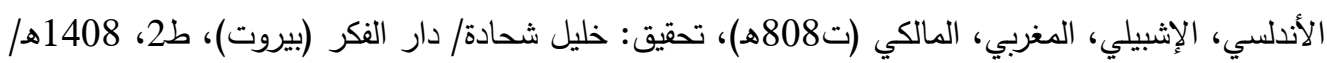
1988

مقدمة الصحاح: الأستاذ أحمد عبدالغفور عطار/ تقديم: الأستاذ عباس محمود العقاد/ دار العلم للملايين

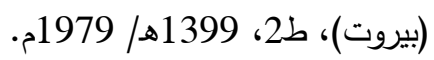
من قضايا اللغة العربية المعاصرة: المنظمة العربية للتربية والثقافة والعلوم بجامعة الدول العربية/ الأستاذ محم

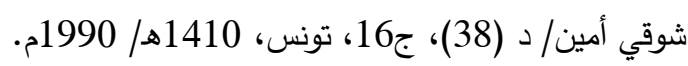

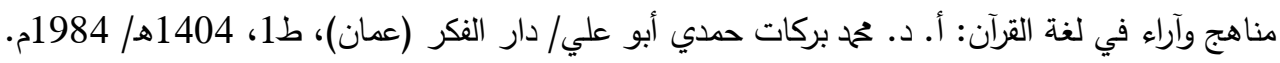

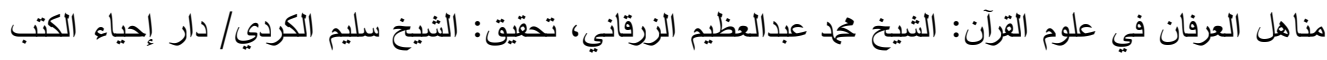

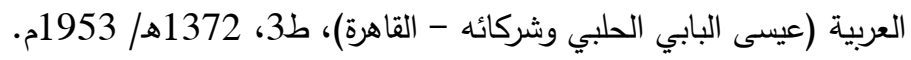

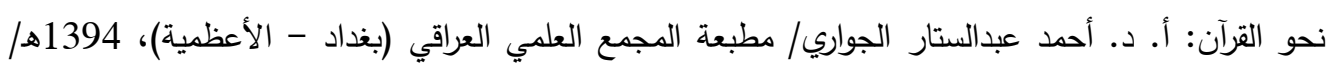
1974

\section{IJHER}

